\title{
Review \\ Overview of Approaches to Improve Rhizoremediation of Petroleum Hydrocarbon-Contaminated Soils
}

\author{
Fahad Alotaibi ${ }^{1,2}$, Mohamed Hijri ${ }^{1,3}$ and Marc St-Arnaud ${ }^{1, *(\mathbb{D}}$ \\ 1 Biodiversity Centre, Institut de Recherche en Biologie Végétale, Université de Montréal and Jardin Botanique \\ de Montréal, Montréal, QC 22001, Canada; fanalotaibi@ksu.edu.sa (F.A.); \\ mohamed.hijri@umontreal.ca (M.H.) \\ 2 Department of Soil Science, King Saud University, Riyadh 11564, Saudi Arabia \\ 3 African Genome Center, Mohammed VI Polytechnic University (UM6P), Ben Guerir 43150, Morocco \\ * Correspondence: marc.st-arnaud@umontreal.ca
}

Citation: Alotaibi, F.; Hijri, M.; St-Arnaud, M. Overview of

Approaches to Improve

Rhizoremediation of Petroleum Hydrocarbon-Contaminated Soils. Appl. Microbiol. 2021, 1, 329-351. https://doi.org/10.3390/ applmicrobiol1020023

Academic Editor: Katarzyna Turnau

Received: 26 May 2021

Accepted: 6 August 2021

Published: 10 August 2021

Publisher's Note: MDPI stays neutral with regard to jurisdictional claims in published maps and institutional affiliations.

Copyright: (C) 2021 by the authors. Licensee MDPI, Basel, Switzerland. This article is an open access article distributed under the terms and conditions of the Creative Commons Attribution (CC BY) license (https:/ / creativecommons.org/licenses/by/ $4.0 /)$.

\begin{abstract}
Soil contamination with petroleum hydrocarbons (PHCs) has become a global concern and has resulted from the intensification of industrial activities. This has created a serious environmental issue; therefore, there is a need to find solutions, including application of efficient remediation technologies or improvement of current techniques. Rhizoremediation is a green technology that has received global attention as a cost-effective and possibly efficient remediation technique for PHCpolluted soil. Rhizoremediation refers to the use of plants and their associated microbiota to clean up contaminated soils, where plant roots stimulate soil microbes to mineralize organic contaminants to $\mathrm{H}_{2} \mathrm{O}$ and $\mathrm{CO}_{2}$. However, this multipartite interaction is complicated because many biotic and abiotic factors can influence microbial processes in the soil, making the efficiency of rhizoremediation unpredictable. This review reports the current knowledge of rhizoremediation approaches that can accelerate the remediation of PHC-contaminated soil. Recent approaches discussed in this review include (1) selecting plants with desired characteristics suitable for rhizoremediation; (2) exploiting and manipulating the plant microbiome by using inoculants containing plant growth-promoting rhizobacteria (PGPR) or hydrocarbon-degrading microbes, or a combination of both types of organisms; (3) enhancing the understanding of how the host-plant assembles a beneficial microbiome, and how it functions, under pollutant stress. A better understanding of plant-microbiome interactions could lead to successful use of rhizoremediation for PHC-contaminated soil in the future.
\end{abstract}

Keywords: phytoremediation; PGPR; hydrocarbon-degrading bacteria; Salix; contaminated soils; alkanes; PAHs

\section{Introduction}

Industrial activities, including mining and extraction of oil and gas, as well as chemical inputs into agricultural production systems, have led to different degrees of environmental contamination worldwide. Petroleum hydrocarbons (PHCs) are among the major pollutants that can pose a serious environmental threat. PHC products have adversely affected various ecosystems, causing disturbing damage to natural habitats with serious economic consequences [1].

PHCs are heterogeneous organic mixtures composed of carbon and hydrogen atoms arranged in varying structural configurations and have different physical and chemical properties [2]. These compounds consist mainly of hydrocarbons and fewer numbers of other non-hydrocarbon constituents, such as nitrogen, oxygen, and sulfur [3,4]. They are broadly classified into two major fractions: aliphatic hydrocarbons and aromatic hydrocarbons (Figure 1). Prior to processing, PHCs are composed, on average, of $\sim 57 \%$ aliphatic hydrocarbons, $\sim 29 \%$ aromatic hydrocarbons, and $\sim 14 \%$ asphaltenes and other polar compounds containing nitrogen, oxygen, and sulfur [5]. Aliphatic hydrocarbons include both linear or branched-chain hydrocarbons, which may be unsaturated (alkenes and alkynes) or 
saturated (alkanes) [6]. Aromatic hydrocarbons include monocyclic (i.e., benzene, toluene, phenol, etc.) and polycyclic aromatic hydrocarbons (PAHs) (Figure 1). PHCs are the most common pollutants in soil and ground water worldwide. The ever-increasing dependency of modern society on fuel for energy generation in many vital sectors, such as electricity, heat, industry, and transportation has resulted in the extensive exploitation of PHCs [2]. Although environmental transition actions have been taken in many countries, dependency on petroleum will last for some decades, contributing to organic pollution risks.

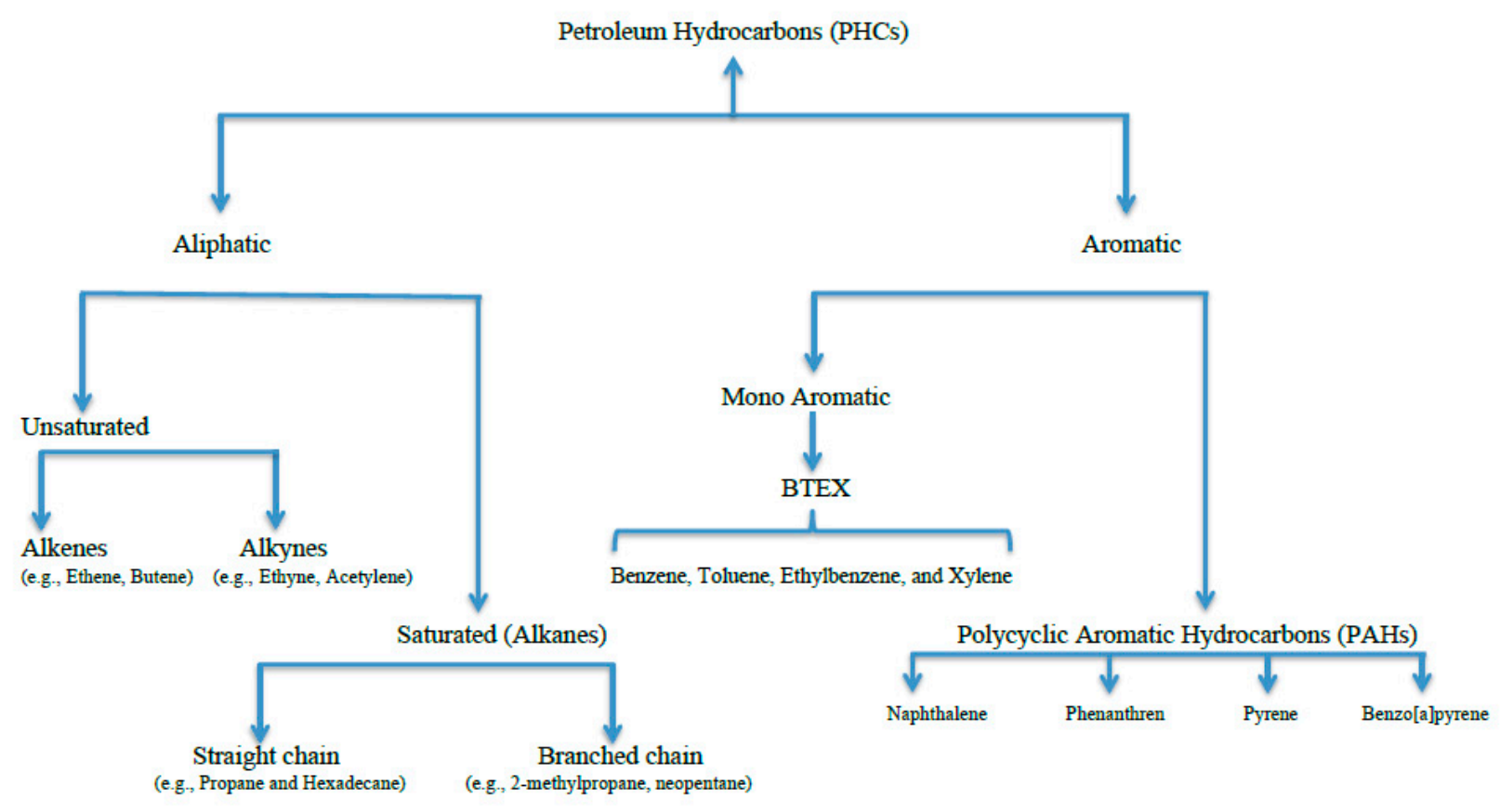

Figure 1. Schematic diagram showing the classification of PHCs.

Soil contamination with PHCs is an international issue, and the magnitude of soil pollution is hard to quantify. For example, in Australia, around 80,000 sites are estimated to be contaminated by PHCs [7], whereas in Canada around 22,000 federal-owned sites are identified as being contaminated by PHCs [8]. In Europe, PHC contamination was observed in at least 342,000 sites [9]. These organic contaminants also pose serious health risks to humans and other organisms in addition to their adverse impact on the soil microflora, leading to environmental quality degradation. For instance, some aromatic substances, such as BTEX and PAHs, are notorious mutagens and carcinogens that can enter our food chain together with lipophilic compounds [10], and they have been linked with probable causes of bladder, kidney, liver, lung, and skin cancers. This explains the growing concern with these contaminants and the urgent need to use all possible means to protect the environment and to find the appropriate techniques to remediate polluted soils.

Various chemical, physical, and thermal conventional techniques have been used to remediate soils contaminated with PHCs. These conventional methods, which can contain, destroy, or separate the pollutants, include a wide range of both in situ and ex situ cleanup technologies, such as asphalt batching, biopiles, chemical oxidation, excavation, hydrolysis, incineration, photolysis, pump and treat, multi-phased slurry reactors, soil vapor extraction, soil washing, and thermal desorption. However, these methods have particular limitations. First, their cost is often prohibitive; for example, it can cost between USD 480 and 813 per $\mathrm{m}^{3}$ for extraction [11]. Second, chemical procedures only work for specific organic compounds, and they most often destroy soil microbial communities. Third, these methods do not often result in a complete degradation of the pollutants [2,12]. Finally, PHC-contaminated soil contains numerous classes and types of toxic organic compounds, which make the choice of the proper method a challenging task. Hence, phytoremediation is a more recent 
and promising green-biotechnology that is perceived as an environmentally friendly, more cost-effective, and less destructive approach to cleanup contaminants in the environment.

\section{Phytoremediation}

Phytoremediation is a remediation technique that relies on the ability of plants and their associated microbiomes to accumulate, degrade, sequester, or stabilize harmful environmental contaminants $[13,14]$. Over the past two decades, the deployment of plants (and their associated microbiomes) to remediate a wide spectrum of inorganic and organic pollutants in soil and water environments has been carried out. This technique has been applied to remediate various types of pollutants such as chlorinated solvents [15], explosives [16], heavy metals [17], landfill leachates [18], pesticides [19], PHC [20], radionuclides [21], and salts [22]. Although phytoremediation is still very much in its infancy, its application has been adopted by a growing number of companies. For example, the phytoremediation market has grown continuously at a rapid rate, with an estimated value of USD 32.2 billion in 2016 and is expected to reach USD 65.7 billion by 2025 [23].

Phytoremediation is an innovative technique that has gained broad public acceptance, not only because it is an environmentally friendly approach but also as it requires less maintenance efforts, minimize site disturbance, and cost-effective process, which is powered by solar energy. However, phytoremediation still remains a marginal option for in situ soil remediation [24]. As any other technique, phytoremediation has some limitations that affect its efficiency, performance, and time consuming. For example, phytoremediation efficiency varies with environmental conditions, such as soil physiochemical properties, contaminant level, and seasonal temperature fluctuations $[13,25,26]$.

Phytoremediation efficiency is dependent on many factors, including plant selection [27]; environmental parameters such as nutrient status, contaminant concentration, and bioavailability; soil $\mathrm{pH}$, etc. [25], in addition to the composition and activity of plantassociated microbiomes. Plants and their associated microbiomes facilitate pollutant uptake from the environment via different processes, including degradation, extraction, stabilization, transformation, and volatilization $[13,14]$. The type of plant and pollutants plus the environmental conditions are key factors for determining the way in which phytoremediation techniques can be applied. Generally, phytoremediation technologies are divided into five different categories (Table 1). The phytoremediation method suitable for petroleum hydrocarbon-contaminated soil is called rhizoremediation [28], which is defined as the breakdown of organic pollutants by using plants and their root-associated microbiomes.

Table 1. Phytoremediation mechanisms whereby plants remediate polluted soils.

\begin{tabular}{|c|c|c|c|c|}
\hline Category & Mechanism & Target Pollutants & Region of Activity & Reference \\
\hline Phytoextraction & $\begin{array}{l}\text { Uptake and concentrate } \\
\text { contaminants }\end{array}$ & $\begin{array}{l}\text { Metals (e.g., } \mathrm{Cd}, \mathrm{Ni}) \\
\text { radionuclides (e.g., } \mathrm{Pu})\end{array}$ & Shoot tissue & {$[21,29]$} \\
\hline Phytostabilization & $\begin{array}{l}\text { Immobilization and } \\
\text { sequestration of contaminants }\end{array}$ & $\begin{array}{l}\text { Primarily metals (e.g., } \mathrm{Cu}, \\
\mathrm{Zn}, \mathrm{Pb})\end{array}$ & Root tissue & {$[30]$} \\
\hline Phytotransformation & Enzymatic actions & $\begin{array}{l}\text { Chlorinated solvents, } \\
\text { ammunition waste, herbicides, } \\
\text { monoaromatic hydrocarbons }\end{array}$ & Plant tissue & {$[15,30]$} \\
\hline Phytovolatilization & $\begin{array}{c}\text { Uptake and } \\
\text { evapotranspiration }\end{array}$ & $\begin{array}{l}\text { Volatile organics (e.g., TCE, } \\
\text { toluene, MTBE), }\end{array}$ & Shoot tissue & [14] \\
\hline Rhizoremediation & $\begin{array}{l}\text { Breakdown of organic } \\
\text { pollutants by using plants and } \\
\text { root-associated microbiomes }\end{array}$ & $\begin{array}{l}\text { PHC (e.g., diesel), pesticides } \\
\text { (e.g., dimethomorph) }\end{array}$ & Root & {$[19,28]$} \\
\hline
\end{tabular}

Adapted and modified from [14,28-30]. 
Rhizoremediation of PHCs is facilitated through a process known as the 'rhizosphere effect' [31], in which plants exude a variety of organic compounds into their rootsurrounding zone (the rhizosphere), resulting in an increase in abundance and activity of certain rhizospheric microbes, which in turn can degrade or metabolize hydrocarbon contaminants [32]. Understanding the plant-microbiome partnerships, and the underlying processes that govern and control PHC degradation, is a priority challenge in rhizoremediation research nowadays $[2,33,34]$.

\section{The Rhizosphere Microbiome}

By definition, the rhizosphere refers to the narrow zone of nutrient-rich soil in close proximity to plant roots and influenced greatly by plant exudates [35]. The rhizosphere is a hot spot for a myriad of organisms, including algae, archaea, arthropods, bacteria, fungi, nematodes, protozoa, and viruses [36], and it has been estimated that one gram of fresh roots contains up to $10^{11}$ microbial cells representing more than 30,000 prokaryotic species [37]. The structure of the rhizosphere microbiome depends on many factors such as soil type, environmental factors, the period of the year, plant development stage, and plant species and genotypes [38]. The rhizosphere microbiome is part of the larger root microbiome that also includes the rhizoplane microbiome and root interior microbiome (endophytes) [39] (Figure 2). The rhizosphere microbiome is one of the most complex habitats on our planet, and microbial functions occurring within the rhizosphere have critical influences on plant growth and productivity, soil fertility, carbon sequestration, and degradation of environmental contaminants [37].

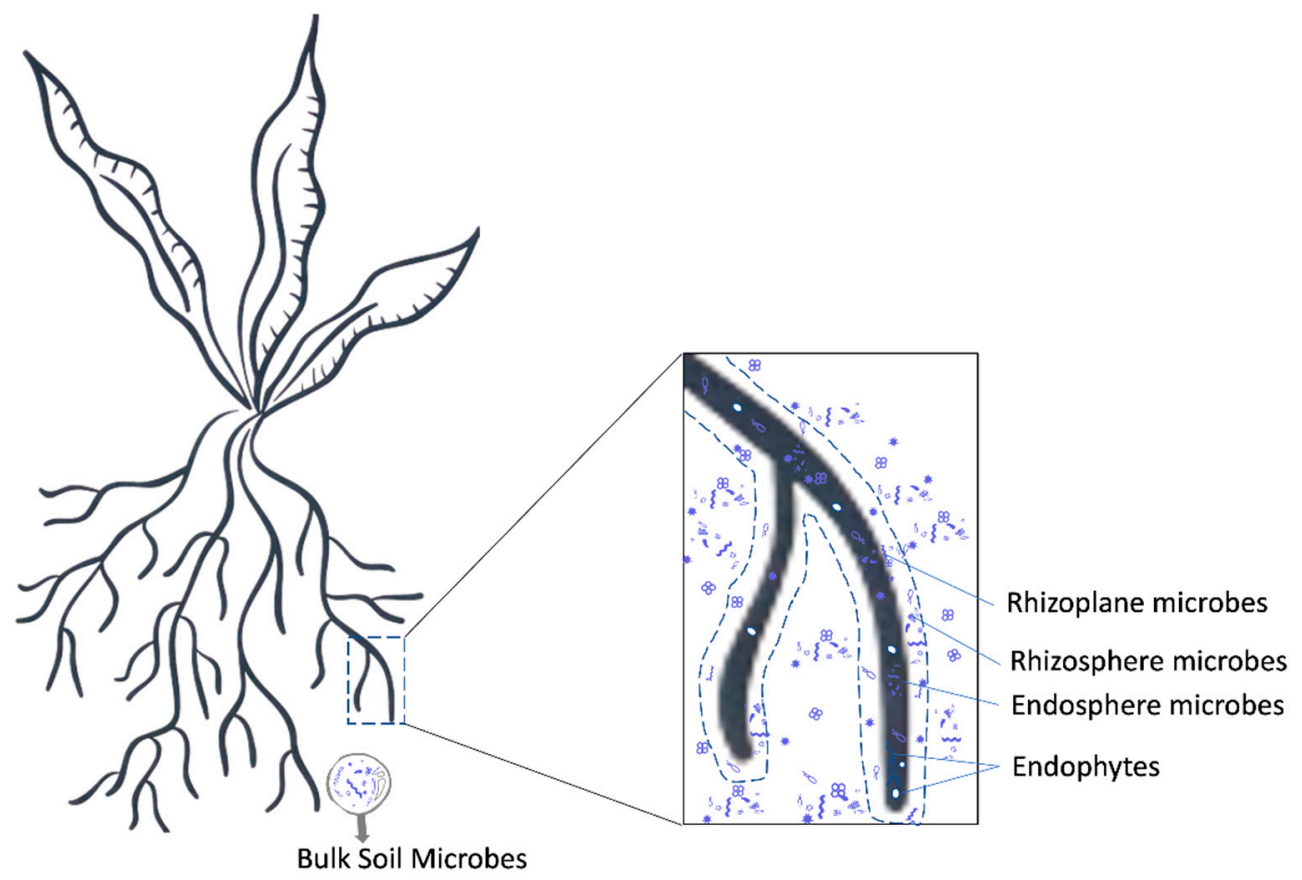

Figure 2. Model of the root microbiome.

Plant roots exude a myriad of organic substances into the surrounding soil, comprising both low molecular weight organic compounds (amino acids, organic acids, sugars, phenolics, secondary metabolites, etc.) and high molecular weight organic compounds (polysaccharides, proteins, etc.). It has been estimated that $6-21 \%$ of photosynthetically fixed carbon in plants is released through root systems [7]. Therefore, root exudates are the major driver in shaping the rhizosphere microbiome. This countless and steady release of fixed carbon compounds into the rhizosphere, a process referred to as the rhizosphere effect, increases the activity and abundance of the rhizosphere microbial community compared to nearby bulk soil $[40,41]$. The magnitude of bacterial density in the rhizosphere is 10 to 
1000 times higher than that in adjacent bulk soil; however, microbial community diversity in the rhizosphere is generally lower than that of bulk soils since rhizodeposition selectively enhances specific microbial taxa [37,42]. Although recruitment of the rhizosphere microbiome by plants is strongly dependent on the structure and composition of the bulk soil microbiota [43], different plant genotypes were found to select for different rhizosphere microbiomes [44], inferring that differential recruitment of beneficial microbiomes is also dependent on the genetic variation across plant species [43,44].

In addition to shaping the microbial communities in the rhizosphere, root exudates have other functions that benefit the plant itself. Through root exudation, plants can change the soil physicochemical properties, contributing to nutrient assimilation, reducing the growth of competitor plant species, increasing the abundance of certain beneficial microbes, and regulating the microbiome composition in the rhizosphere [45,46].

The important role of root exudation, secreted by plants growing in PHC-contaminated soils, as facilitators of hydrocarbon rhizoremediation has been recognized recently $[33,47]$. This microbial process can function through different mechanisms. First, root exudates include degradable low molecular weight organic compounds such as carbohydrates, amino acids, and organic acids, all of which are readily available energy and nutrient sources for microbial utilization, stimulating the proliferation of microbial biomass and activities [28]. For instance, the addition of sugar and amino acids into soils causes an instant response (within $1 \mathrm{~h}$ ) in microbial respiration [48]. Additionally, compounds essential in plant nutrient acquisition secreted by roots, such as enzymes (e.g., acid phosphatases) and chelating agents (phytosiderophores), provide microbial communities in the rhizosphere with a source of nutrients [47]. Second, plant root exudation can enhance PHC degradation by emitting a wide range of enzymes, such as cytochrome P450 monooxygenases, dehalogenases, dioxygenase, laccases, and peroxidases [7,32,49]. Plant-secreted enzymes play a key role in the oxidation of PHCs [50], and the initial attack on the pollutant itself is primarily performed by soil microbial enzymes [50]. Third, secondary metabolites released by the plant roots, such as flavonoids and phenols, are analogous to many organic pollutants, thus increasing the abundance and activity of microbial communities equipped with genes relevant to degradation of organic pollutants within the rhizosphere, even in unpolluted soils [51]. Fourth, root-released exudates have been shown to increase the availability of organic pollutants for microbial metabolisms [32]. For example, Gao et al. [52] reported that the availability of phenanthrene and pyrene increased in the soil after the addition of citric acid and oxalic acid.

Considering the above-mentioned role of root exudates, the rhizosphere is hypothesized to be a suitable niche for rhizoremediation of PHC-contaminated soil [33]. Additionally, the rhizosphere is one of the environmental niches that is conducive to horizontal gene transfer (HGT) [53]. HGT is a mechanism used by bacterial communities to adapt to the presence of organic contaminants in their environments [54]. Bacteria may acquire genetic information from either closely related or phylogenetically distinct taxa in the community by HGT via different routes, such as plasmids and transposons [54]. Several studies have reported that plasmids were shown to help bacterial communities adapt to environmental pollution stress $[54,55]$.

To overcome the limitations and improve the efficiency of rhizoremediation, current research trends focus on several auxiliary strategies, such as (1) selecting plants with desired characteristics suitable for rhizoremediation (such as increased contaminant tolerance or production of vigorous root system and shoot biomass [27], but also abilities to form symbiotic interactions with microorganisms); (2) exploiting and manipulating the plant microbiome by using inoculants containing plant growth-promoting rhizobacteria (PGPR) or hydrocarbon-degrading microbes or their combination [33]; and (3) enhancing the understanding of the mechanisms through which host plants assemble a beneficial microbiome, and how it functions, under pollutant stress [34]. 


\subsection{Plant Selection}

Since the beginning of phytoremediation research, many plant species have been tested for their potential to enhance rhizoremediation of PHCs [56]. Plants enhance the degradation of PHCs principally by the unique properties of the plant itself and by providing optimal conditions for microbial proliferation in the rhizosphere [57]. In general, selection of plants suitable for rhizoremediation of PHCs should be based on the following criteria: tolerance to a broad range of PHCs, speed of growth, root morphology, ability to grow in many soil types, and the root exudate profile [57-59]. Additionally, plants should not be selected based solely on the contaminant uptake efficiency; their ability to stimulate microbial activity and abundance also should be considered $[60,61]$.

Plants that have been used thus far in rhizoremediation span a wide range of families. Grasses (annual ryegrass, tall fescue) and other herbaceous crops (Indian mustard, sunflower), legumes (alfalfa, clover), and woody trees (hybrid poplars, willows), among others, have shown a high potential in the rhizoremediation of soil contaminated with PHCs [60,62].

Grasses have been studied extensively regarding their potential to facilitate the rhizoremediation of PHC-impacted soil [59]. Grasses are often chosen for rhizoremediation applications because of their fast growth, high tolerance to PHCs, extensive fibrous root systems, large root surface area, and deeper root penetration into the soil matrix to depths of up to $3 \mathrm{~m}[58,62]$. These unique characteristics of grass root systems allow microbial colonization and establishment of abundant microbial populations. For example, bacterial populations found in the rhizosphere of goosegrass (Eleusine indica) cultivated in PHC contaminated soil were 72 times more abundant than bacterial populations observed in the nearby uncultivated soil [63].

Legumes have also been tested for their potential to enhance rhizoremediation of PHCcontaminated soil [60]. The remarkable ability of legumes to form symbiotic relationships with the N-fixing rhizobia is of great importance in PHC-contaminated soil, which is characterized by low nutrient availability and high $\mathrm{C} / \mathrm{N}$ ratio [62]. In addition, some legumes species such as alfalfa have a deep-rooting system that can penetrate highly compacted soil layers and create soil macropore spaces, thus increasing oxygenation of the soil matrix and, consequently, promoting microbial degradation [60].

Trees, such as willows (Salix), have also gained attention regarding their potential to improve rhizoremediation of PHC-polluted soil [2]. Willows are attractive for rhizoremediation of PHCs because they are easy to propagate, exhibit extremely fast growth in low-fertility soils, have high tolerance to several stressful environments, produce large biomass, and generate widespread deep-rooting systems [64]. Additionally, the large diversity of willows ( $\sim 350-500$ genetically distinct species), with a wide range of tolerance to various environmental conditions, facilitates selection of the most appropriate species suitable for a particular environment [64]. Compelling evidence has been reported about the use of willows for the rhizoremediation of soils polluted with organic contaminants, including PHCs [65-67].

More recently, promising approaches including the screening and identification of native plants grown on PHC-contaminated soil have been used. For example, PérezJaramillo et al. [68] proposed a "back to the roots" framework that involves surveying indigenous plants and associated microbiomes, and their native habitats, to identify plants and microbial traits with the goal to restore associations that may have been diluted during plant domestication [68]. In fact, using native plant species in rhizoremediation offers many advantages over non-native species, including minimizing the potential of introducing alien species that can became invasive and disturb local flora and fauna [69], in addition to the fact that indigenous plants are more genetically diverse and more adapted to a wide range of climatic conditions compared to other plants currently chosen for rhizoremediation [70]. Following this approach, Desjardins et al. [71] described plants growing spontaneously in highly petroleum-contaminated decantation basins of a former petrochemical plant in Varennes (southern Québec, Canada) and identified three plants species (Alisma triviale, 
Eleocharis obtusa, and Panicum capillare) that were tolerant to PAHs and PHCs. Additionally, Lee et al. [72] studied the diversity of arbuscular mycorrhizal fungal communities of native plant species grown in highly PHC-contaminated soil and identified Rhizophagus as a key PHC-tolerant genus. Arbuscular mycorrhizal fungi (AMF) are obligate symbionts with approximately $80 \%$ of plant species on earth [73]. In agricultural settings, AMF are known for their plant growth-promoting effects including improved plant uptake of mineral nutrients, in particular phosphorus [74]. Additionally, AMF were shown to enhance plant tolerance toward several biotic and abiotic stresses such as nutrient deficiencies, plant pathogens, drought, salinity, and contaminants [74-78]. Therefore, AMF have more recently gained attention regarding their use in phytoremediation of soils contaminated with different pollutants, such as heavy metals and PHCs [72,79,80].

Sequestration and transportation of contaminants inside plant tissues enable plants to remediate PHC-polluted soil [81,82]. Plants can also degrade or transform organic pollutants into less toxic forms via their enzymatic machinery, or synthesizing a variety of defensive proteins and metabolites $[13,83]$. Therefore, plants can adapt and confront many unfavorable stressful conditions, such as PHC contamination. However, plant growth has been retarded under highly stressed conditions, e.g., PHC pollutants are expected to be lower than those under optimal conditions [84]. Therefore, plant growth may be positively enhanced by the presence of plant growth-promoting rhizobacteria (PGPR) that are able to alleviate stresses in plants via many mechanisms, such as reducing soil nutrient deficiencies (fixing nitrogen, solubilizing phosphorus, and enhancing iron uptake), synthesizing plant hormones, suppressing ethylene production via 1-aminocyclopropane-1-carboxylate (ACC) deaminase activity [84,85], and degrading a broad range of PHCs [2].

\subsection{Exploiting and Manipulating the Plant Microbiome through Inoculation}

\subsubsection{Plant Growth-Promoting Rhizobacteria (PGPR)}

Bacteria are the predominant group within the soil microbiome community. It has been estimated that one gram of soil contains around $10^{8}-10^{9}$ bacterial cells [86] representing tens of thousands of different species [37]. The capacity of bacteria to utilize a wide range of many compounds as nutrient and energy sources, and their diverse metabolism, make them ideal associates in plant-microbiome partnerships [37]. Among bacterial communities dwelling in the rhizosphere are PGPR. PGPR are free-living and beneficial soil-borne bacteria associated with the root microbiome, enhancing plant growth and development by direct and indirect means [87-89]. The direct means by which PGPR may promote plant growth occur through fixing atmospheric $\mathrm{N}$, increasing nutrient acquisition such as phosphorous, stimulating plant growth by producing different phytohormones, sequestration of iron by synthesis of siderophores, and alleviating stresses in plants by producing 1-aminocyclopropane-1-carboxylate (ACC) deaminase [88,89]. Indirect means of growth stimulation occur through biocontrol activities of PGPR against many plant phytopathogens via different mechanisms, including production of antimicrobial metabolites such as siderophores, antibiotics, and bacteriocins as well as induced systemic resistance (ISR) in plants $[90,91]$.

A plethora of bacterial genera, such as Acetobacter, Acinetobacter, Arthrobacter, Azospirillum, Azotobacter, Bacillus, Burkholderia, Caulobacter, Chromobacterium, Flavobacterium, Enterobacter, Erwinia, Herbaspirillum, Klebsiella, Micrococcus, Paenibacillus, Rhizobium, Pseudomonas, Serratia, Stenotrophomonas, Streptomyces, Variovorax, and Xanthomonas have been shown to stimulate plant growth and development $[88,89]$. These phylogenetically diverse bacterial group have wide spectrum plant growth-promoting capabilities, and they can be categorized as biocontrol, biofertilizer, and phytostimulation agents [89,91,92].

\section{Enhanced Nutrient Acquisition (Biofertilizer)}

A major mechanism used by PGPR to stimulate crop growth and development is biofertilization. Several mineral nutrients, such as nitrogen, phosphorus, and iron can be limited in the soil, thus limiting plant growth and development [92]. Nitrogen is 
the most liming factor for crop growth, although the geosphere contains $1.6 \times 10^{17} \mathrm{t}$, most of which is found in the atmosphere with an estimated $3.86 \times 10^{15} \mathrm{t}$ [93]. Nitrogen $\left(\mathrm{N}_{2}\right)$ represents around $78 \%$ of the atmosphere, and it is inaccessible to all plants and other eukaryotic life. Biological nitrogen fixation (BNF) is a process carried out by a few adapted prokaryotic diazotroph, that possess the enzyme nitrogenase, which catalyzes the reduction of $\mathrm{N}_{2}$ to ammonia, a form of $\mathrm{N}$ utilized by plants [94]. Diazotrophic bacteria can be classified according to the degree of intimacy with plants: symbiotic $\mathrm{N}$-fixing bacteria, such as rhizobia, associative $\mathrm{N}$-fixing bacteria, such as Azospirillum spp., and free-living $\mathrm{N}$-fixing bacteria, such as Azotobacter spp. [89]. The efficiency and significant contribution of BNF from PGPR is well documented for several crops such as legumes, sugarcane, and grasses [94-96].

The other major nutrient limiting plant growth is phosphorus (P). Although soil often has abundant quantities of $\mathrm{P}(\sim 0.05 \% w / w)$, only a small fraction of this $\mathrm{P}(\sim 0.1 \%)$ is readily available for plant uptake $[97,98]$. Low availability of $P$ in soils is due to the fact that the majority of soil-bounded $\mathrm{P}$ is present in insoluble form [98]. Plants can take-up $\mathrm{P}$ in two soluble forms, either as monobasic $\left(\mathrm{H}_{2} \mathrm{PO}_{4}{ }^{-}\right)$or dibasic $\left(\mathrm{HPO}_{4}{ }^{2-}\right)$ ions [99]. A subset of bacteria, known as phosphate solubilizing bacteria (PSB), can influence the availability of P $[100,101]$. PSB are commonly found in the rhizosphere of plants and encompass genera such as Azotobacter, Bacillus, Bradyrhizobium, Burkholderia, Enterobacter, Ralstonia, Rhizobium, Rhodococcus, Paenibacillus, Pseudomonas, and Serratia [87,97]. These PSB can solubilize insoluble forms of $\mathrm{P}$ to plant-available forms through different mechanisms, such as the secretion of organic acids, siderophores, protons, hydroxyl ions, and $\mathrm{CO}_{2}$, as in the case of inorganic P solubilization [101,102]. These bacteria also produce many extracellular enzymes, such as acid and alkaline phosphatases and phytases that stimulate organic $\mathrm{P}$ mineralization [100,101,103].

Iron is another essential plant nutrient that plays a key role in plant growth and development. Despite its abundancy in the soil, most of iron is present in insoluble forms, mainly as ferric hydroxide [104]. Plant roots prefer to take-up the reduced form of iron, the ferrous $\left(\mathrm{Fe}^{+2}\right)$ ion compared to the ferric $\left(\mathrm{Fe}^{+3}\right)$ ion [89]. Siderophores are low-molecular-weight iron-chelating agents that are produced by many soil bacteria and fungi under stressed low iron conditions [105]. Bacterial produced-siderophores can enhance plant growth by enhancing plant iron nutrition through binding $\mathrm{Fe}^{+3}$ and render it available for reduction to $\mathrm{Fe}^{+2}[89,92]$. Apart from improving plant iron nutrition, siderophores also stimulate plant growth indirectly via suppressing plant pathogen activities in the rhizosphere by depriving pathogens of $\mathrm{Fe}^{+2}$ required for their cellular growth and development, thus lowering the probability of plant disease [91]. Additionally, siderophore-producing bacteria were shown to play an important role in enhancing plant growth in heavy metal-contaminated soils by alleviating heavy metal toxicity $[106,107]$. Several reports indicated that microbial siderophores bind and form stable compounds with other heavy metals such as $\mathrm{Al}, \mathrm{Cd}, \mathrm{Cu}$, $\mathrm{Pb}$, and $\mathrm{Zn}[106-108]$.

In addition to pseudomonads, which synthesize high-affinity $\mathrm{Fe}^{3+}$-binding siderophores [109], several other PGPR are capable of producing siderophores including Azospirillum spp., Azotobacter spp., Bacillus spp., Klebsiella spp., Nocardia spp., Paenibacillus spp., Pantoea spp., Serratia spp., and Streptomyces spp. [89,105].

The role of PGPR in solubilizing and oxidizing other essential plant nutrients, such as potassium, sulfur, and micronutrients, and their effects on plant growth-promotion are far less studied compared to N, P, and Fe. For more information regarding the role of PGPR in providing these elements to plants, the reader can consult recent publications on this topic $[110,111]$.

\section{Plant Growth Regulation (Phytostimulation)}

Other direct modes of action employed by PGPR to stimulate plant growth and development is through production of phytohormones [92]. Various PGPR are known to synthesize different classes of phytohormones, including abscisic acid (ABA), auxins, 
ethylene, gibberellins, and cytokinins [89,92]. These phytohormones are responsible for many processes in plants during their different development stages. Auxins, for example, are responsible for cell enlargement and cell division, root initiation, increased fruit development, and leaf senescence [112]. Cytokinins on the other hand play a major role in the promotion of cell division and root hair formation, initiation, and expansion of shoots and other plant parts, and decreased root growth [113]. Phytohormone gibberellins take part in regulating seed dormancy and germination, speeding up fruit and flowering processes, and modifying plant morphology, particularly stem elongation [114,115]. When produced at low concentration, the plant growth regulator ethylene is involved in many plant growth stages including stimulation of seed germination, formation and elongation of roots, and fruit and leaf maturation [116]. Finally, the phytohormone ABA plays main roles in seed development and maturation and mediating stomatal opening [115]. The most studied phytohormone, to date, produced by PGPR is auxin indole-3-acetic acid (IAA), which is involved in enhancing root growth and root length as well as formation and proliferation of lateral root hairs [112]. IAA-synthesizing PGPR include bacterial genera such as Aeromonas, Agrobacterium, Alcaligenes, Azospirillum, Bradyrhizobium, Comamonas, Bacillus, Bradyrhizobium, Burkholderia, Enterobacter, Rhizobium, and Pseudomonas [89,117,118].

\subsubsection{Reduction of Plant Ethylene (Stress Alleviating)}

Ethylene production by plants at low concentrations can be beneficial, as mentioned above. However, when produced at high concentrations, it can stunt plant growth and development by inhibiting root growth [119]. In response to various biotic and abiotic stressor conditions, plants synthesize different enzymes, metabolites, and stress proteins to alleviate the adverse effects of stress [120]; of particular interest is ethylene. Once plants encounter stress, such as flooding, drought, or presence of toxic compounds, plant growth is inhibited because the ethylene precursor, 1-aminocyclopropane-1-carboxylate, is induced [121]. However, certain PGPR can hinder ethylene biosynthesis via production of 1-aminocyclopropane-1-carboxylate deaminase (ACCD) that cleaves the ethylene precursor ACC into alpha-ketobutyrate and ammonia [122], thus balancing ethylene levels and reducing its adverse impact on plant growth [122].

The beneficial roles of PGPR-containing ACCD have been studied in plants grown under different stress conditions, such as drought [123], waterlogging [124], high salinity [125], and heavy metal contamination [126]. Several PGPR are known for their production of ACCD such as Achromobacter spp., Azotobacter spp., Bacillus spp., Enterobacter spp. Herbaspirillum spp., Ochrobactrum spp., Pseudomonas spp., and Serratia spp. [122-126].

\section{Plant Growth-Promoting Rhizobacteria-Assisted Phytoremediation}

Over the last few decades, the immense interest in exploiting PGPR as a biofertilizer or biocontrol agent in agriculture has resulted in the development of successful commercial inoculants in many parts of the world, including Canada, Europe, and the United States [127-129]. Considerable research investigations have been conducted over the last decade to utilize PGPR in bioremediation of heavy metal-contaminated soils by promoting plant growth and also ameliorating the phytostabilization or phytoextraction efficiency [130-132]. However, the utilization of PGPR in rhizoremediation of PHCcontaminated soil is new and represents a large, untapped potential [2,33]. Recent reports of PGPR-assisted phytoremediation of PHC-contaminated soil and its host plants are summarized in Table 2. 
Table 2. Examples of the use of PGPR in rhizoremediation of PHC-contaminated soil.

\begin{tabular}{cccccc}
\hline Plant & Contaminants & Conditions & Bacteria & Role of PGPR & Reference \\
\hline Lolium perenne & Diesel & Greenhouse & Pantoea sp. BTRH79 & ACCD & [133] \\
\hline Cytisus striatus & Diesel & Greenhouse & Bradyrhizobium sp. ER33 & IAA, organic acids & [134] \\
\hline Lupinus luteus & Diesel & Greenhouse & $\begin{array}{c}\text { Streptomyces sp. RP92 } \\
\text { [134] }\end{array}$ & $\begin{array}{c}\text { IAA, siderophore, } \\
\text { organic acid }\end{array}$ \\
\hline Trifolium repens & Oil refinery sludge & Field trial & Psudomonas putida BIRD-1 & $\begin{array}{c}\text { P-solublization, } \\
\text { IAA, siderophore }\end{array}$ & [135] \\
\hline Festuca arundinacea & $\begin{array}{c}\text { Aliphatic } \\
\text { hydrocarbons }\end{array}$ & Field trail & PGPR consortia & N/A & [136] \\
\hline Lolium perenne & Aged PHCs & Greenhouse & $\begin{array}{c}\text { Rhodococcus erythropolis } \\
\text { CDEL254 }\end{array}$ & Several PGP traits & [137] \\
\hline Lolium perenne & Aged PHCs & Greenhouse & $\begin{array}{c}\text { Rhodococcus erythropolis } \\
\text { CD 106 }\end{array}$ & Several PGP traits \\
\hline
\end{tabular}

\subsubsection{Hydrocarbon-Degrading Bacteria}

Ecology and Diversity of PHC-Degrading Bacteria

The fate of most PHCs encountered in the terrestrial environment is degradation and/or biotransformation by soil bacteria. These bacteria are heterotroph thus, they utilize PHC compounds as nutrient and energy sources for their cellular growth and development. PHC-degrading bacteria are widespread in nature and have been found in Arctic and Antarctic soils [139], aquatic environments [140], and pristine environments [141]. The abundance of PHCs in the environment maintains the degradation potential within most bacterial communities [142]. Interestingly, certain obligate hydrocarbonoclastic bacteria (OHCB) such as Alcanivorax spp., Cycloclasticus spp., Marinobacter spp., Oleispira spp. Planomicrobium spp., and Thalassolituus spp. are found undetectable or in low abundance in unpolluted environments; however, they prevail after PHC pollution occurs $[140,143,144]$.

Over the last few decades, many bacterial species have been isolated and identified from various terrestrial and aquatic environments [140,143,145]. Some of these bacteria can utilize a wide spectrum of PHC compounds; for example, the bacterial strain Dietzia sp. DQ12-45-1b could grow on many $n$-alkanes (C6-C40) and other monoaromatic and polyaromatic hydrocarbons as the sole carbon source and energy [146]. To date, more than 79 bacterial genera that can degrade PHCs have been isolated and identified [143,144], such as Achromobacter, Acinetobacter, Alkanindiges, Alteromonas, Arthrobacter, Bacillus, Burkholderia, Dietzia, Enterobacter, Kocuria, Marinobacter, Mycobacterium, Nocardia, Pseudomonas, Rhodococcus, Streptomyces, and Variovorax [144,145,147]. As different bacteria vary in their catalytic enzyme activity, no single bacterial species can break down the entire PHC fraction completely $[144,145]$; therefore, their effectiveness in remediating PHC-polluted sites also varies widely [144].

\section{Alkane-Degrading Bacteria}

Alkanes are saturated hydrocarbons that can be further classified as branched (isoalkanes), cyclic (cyclo-alkanes), or linear ( $n$-alkanes) [148]. Although many living organisms, such as bacteria, plants, and green algae produce alkanes $[149,150]$, the main source of alkanes in terrestrial environments comes from PHC contamination, as alkanes are the main constituent of crude oil and natural gas $[148,151]$. Bacterial alkane degradation is of great significance for the bioremediation of PHC-contaminated soil as well as for microbial enhanced oil recovery [152]. Bacteria metabolize alkanes under both aerobic and anaerobic conditions [148]. Most bacteria degrade alkanes aerobically; therefore, aerobic degradation will be discussed hereafter.

Aerobic degradation of alkanes starts with terminal or sub-terminal incorporation of oxygen atoms $\left(\mathrm{O}_{2}\right)$ into the hydrocarbon substrate by an alkane hydroxylase enzyme [151]. 
Alkane hydroxylases (AHs) are a class of several specific enzymes that insert $\mathrm{O}_{2}$ into the hydrocarbons to initiate degradation [153]. Depending on the chain length of the alkane substrate, there are different enzyme classes that carry out the oxygenation of hydrocarbons [153] (Table 3). For example, bacteria degrading short-chain alkanes (C2-C4) have enzymes related to methane monooxygenases, while bacterial strains degrading medium-chain alkanes (C5-C20) usually contain alkane 1-monooxygenase and soluble cytochrome P450 enzymes, and bacterial strains degrading long-chain alkanes (>C20) contain several recently discovered types of AHs, such as flavin-binding monooxygenase and thermophilic flavin-dependent monooxygenase $[148,151,153,154]$ (Table 3).

Table 3. Examples of alkane-degrading genes, enzymes, and their bacterial sources.

\begin{tabular}{|c|c|c|c|}
\hline Enzyme Class & Substrate Range & Gene & Bacterial Species \\
\hline $\begin{array}{l}\text { Soluble methane } \\
\text { Monooxygenase }\end{array}$ & $\mathrm{C} 1-\mathrm{C} 8$ & $m m o X$ & $\begin{array}{c}\text { Gordonia, Methylococcus, Methylosinus, Methylocystis, } \\
\text { Methylomonas, Methylocella. }\end{array}$ \\
\hline $\begin{array}{l}\text { Particulate methane } \\
\text { Monooxygenase }\end{array}$ & $\mathrm{C} 1-\mathrm{C} 5$ & pmoC & $\begin{array}{l}\text { Methylococcus, Methylosinus, Methylocystis, Methylobacter, } \\
\text { Methylomonas, Methylomicrobium, Nocardioides. }\end{array}$ \\
\hline Alkane 1-monooxygenase & $\mathrm{C} 10-\mathrm{C} 20$ & alkB & $\begin{array}{c}\text { Acinetobacter, Alcanivorax, Burkholderia, Mycobacterium, } \\
\text { Pseudomonas, Rhodococcus }\end{array}$ \\
\hline Soluble cytochrome P450 & C5-C16 & CYP153 & $\begin{array}{c}\text { Acinetobacter, Alcanivorax, Caulobacter, Mycobacterium, } \\
\text { Rhodococcus, Sphingomonas. }\end{array}$ \\
\hline $\begin{array}{l}\text { Flavin-binding } \\
\text { monooxygenase }\end{array}$ & C20-C36 & Alma & Alcanivorax, Marinobacter, Acinetobacter. \\
\hline $\begin{array}{l}\text { Thermophilic } \\
\text { flavin-dependent } \\
\text { monooxygenase }\end{array}$ & C10-C36 & $\operatorname{Lad} A$ & Geobacillus thermodenitrificans NG80-2 \\
\hline
\end{tabular}

Adapted and modified from [148,151,153,154].

Among the above-mentioned (AHs) enzyme systems, alkane 1-monooxygenase (encoded by alkB) is the most common found in alkanes degrading $\alpha-, \beta$-, and $\gamma$-Proteobacteria and high $\mathrm{G}+\mathrm{C}$ content Gram-positive bacteria $[153,154]$. The substrates for AlkB-harboring bacteria comprise alkanes ranging from C10 to C16 [153]; however, some AlkB-harboring Actinobacteria, such as Dietzia sp. and Gordonia sp., can degrade alkanes with chain lengths up to C32 [155,156]. Another bacterial AH enzyme system for degradation of short- and medium-chain substrates is cytochrome P450 hydroxylase of the CYP153 family, which is frequently found in alkane-degrading bacteria lacking the AlkB enzyme $[157,158]$. It is common that bacterial strains contain more than one alkB homologous gene, as in the case of Rhodococcus strain Q15, which contains at least four alkane 1-monooxygenases [159]. Additionally, several bacterial strains have more than one AH system, as has been shown in Dietzia sp. strain DQ12-45-1b, which has AlkB and CYP153 systems co-existing together [158]. The co-existence of more than one $\mathrm{AH}$ system in bacteria can expand its ability to degrade a wider alkane range $[157,158]$. AlkB and CYP153 genes are commonly assessed to determine the degradation potential of bacterial communities in PHC-impacted soil and water environments $[160,161]$.

\section{Polycyclic Aromatic Hydrocarbon-Degrading Bacteria}

The other major fraction of PHCs is polycyclic aromatic hydrocarbons (PAHs). PAHs are ubiquitous in nature. They have two or more aromatic benzene rings in their structure [162]. PAHs are found in nature as a byproduct of many biogeochemical and biological processes as well as incomplete combustion of woods, coal, and gasoline [163]. However, the main entry source of PAHs in the environment is industrial activities related to the petroleum and gas industry $[162,163]$. Due to their electrochemical stability, high persistence in terrestrial environments, bio-accumulative behaviors, and their "multi-faceted disease-causing" effects (carcinogenic, mutagenic, teratogenic), the United States Environ- 
mental Protection Agency (U.S. EPA), as well as agencies in many other countries, has listed 16 PAH compounds as priority pollutants [162,164].

The main principle of PAH biodegradation, mediated by aerobic bacteria, involves activation and subsequent cleavage of the thermodynamically stable benzene ring in PAH substrates [163]. Under aerobic conditions, the initial step is the hydroxylation of the benzene ring by dioxygenase enzymes, resulting in the formation of cis-dihydrodiols. After this step, cis-dihydrodiols are further dehydrogenated, via the action of dehydrogenase enzymes, to form several dihydroxylated intermediates. Subsequently, these diol intermediates are cleaved by intradiol or extradiol ring-cleaving dioxygenase enzymes, leading to the formation of central intermediates, such as protocatechuates and catechols that can be further metabolized to acetone, succinate, or pyruvate, which then enter the tricarboxylic acid cycle (TCA) cycle [165-168].

PAHs are broadly classified into low-molecular-weight (LMW PAHs) compounds with fewer than three rings ( $<3$ rings), and high-molecular-weight (HMW PAHs) compounds with more than three rings ( $>3$ rings) [163]. LMW PAHs such as naphthalene, phenanthrene, anthracene, fluorene, acenaphthene, and acenaphthylene are found in high quantities in PHC-contaminated sites, and diverse bacterial communities have the ability to utilize these LMW PAHs as the sole carbon and energy source $[167,168]$. LMW PAHdegrading bacteria are ubiquitous in nature, and the isolation, degradation potential, and elucidation of catabolic pathways, enzymatic machineries, and genetic regulations within these bacteria are well documented [166-168]. For example, several bacterial genera are well known for their high efficiency to degrade LMW PAHs, such as Acinetobacter, Comamonas, Novosphingobium, Ochrobactrum, Ralstonia, Rhodococcus, Pseudomonas, Sphingomonas, Sphingobium, and Staphylococcus [166-168].

Unlike LMW PAHs, HMW PAHs, due to their stable physicochemical structures, do not biodegrade easily; however, research on bacterial degradation of HMW PAHs has advanced significantly over the last two decades $[168,169]$. Several HMW PAH bioavailabilityenhancing strategies and adaptation mechanisms have been identified and include biofilm formation, cell surface hydrophobicity, low requirements for energy and $\mathrm{O}_{2}$ for cell growth and maintenance, high substrate uptake affinity, production of biosurfactants, and wide substrate utilization patterns $[166,169,170]$. More importantly, the functions of diverse, versatile catabolic genes involved in HMW PAH degradation and enzymatic activities, as well as their regulation mechanisms, have been discovered in various HMW PAHdegrading bacteria [169]. Table 4 lists genes and enzymes involved in both LMW and HMW PAH biodegradation.

Table 4. Examples of PAH-degrading genes, enzymes, and their bacterial source.

\begin{tabular}{cccc}
\hline Enzyme & Gene & Bacterial Source & Reference \\
\hline Naphthalene dioxygenase & Nah & Pseudomonas putida strain G7 & {$[171]$} \\
\hline Phenanthrene dioxygenase & $p h n A c$ & Burkholderia sp. strain RP007 & {$[172]$} \\
\hline Pyrene dioxygenase & $n i d A$ & Mycobacterium sp. strain PYR-1 & {$[173]$} \\
\hline Extradiol dioxygenase & $p h d F$ & Mycobacterium sp. strain SNP11 & {$[174]$} \\
\hline Catechol 1,2-dioxygenase & $C 12 O$ & Pseudomonas sp. strain EST1001 & {$[175]$} \\
\hline
\end{tabular}

Although most of the HMW PAH-degrading bacteria described so far belong to the Actinobacteria phylum, representing genera such as Arthrobacter, Corynebacterium, Dietzia, Gordonia, Microbacterium, Mycobacterium, Nocardia, Rhodococcus, and Streptomyces [1,168], a variety of non-actinomycete bacterial genera such as Achromobacter, Burkholderia, Pseudomonas, Sphingomonas, Sphingobium, and Stenotrophomonas have been reported as well $[166,168]$. 


\section{Enhancing the Understanding of Mechanisms through Which Host Plants Assemble} a Beneficial Microbiome, and How It Functions, under Pollutant Stress

A challenging problem facing studies of the microbiome in many disciplines is the fact that the majority of microbial taxa are resistant to cultivation using current culturedependent techniques. However, over the past decade or so, the advancement of nextgeneration sequencing and bioinformatics has paved the way to enhance our understanding of the structure, function, and composition of microbial communities in different habitats and environmental conditions, including PHC-contaminated soil [176].

\subsection{High-Throughput Amplicon Sequencing}

Studies of the rhizosphere microbiome in natural and agricultural settings have generated most of our knowledge about host plant selection processes and plant-microbiome interactions taking place in the rhizosphere and how plants recruit different microbiota from surrounding environments [34,177]. For example, previous studies using $16 \mathrm{~S}$ rRNA amplicon sequencing revealed that microbial communities in the rhizosphere and adjunct bulk soils are different; the recruitment of rhizosphere microbiota by plants is strongly dependent on the structure and composition of the bulk soil microbiome [43], and different plant genotypes were found to select for different rhizosphere microbiomes [44].

Over the past few years, several experiments have been conducted to optimize phytoremediation systems and improve their efficacy using high-throughput sequencing approaches. For example, Bell et al. [65] used high-throughput 454-pyrosequencing of bacterial 16S rRNA genes and the fungal internal transcribed spacer (ITS) region to compare the community structure and composition of the rhizosphere microbiome of native and non-native Salix cultivars across uncontaminated and PHC-contaminated soil. Their results indicated higher fungal sensitivity to PHC contamination than that found for bacterial communities. Additionally, certain fungal class (Pezizomycetes) reacted differently following plant introduction to soils [65], implying the importance of plant species selection in phytoremediation with regard to their impact on plant-associated microbiomes [34]. Similarly, Hassan et al. [80] used 454-pyrosequencing of the AMF 18S rDNA gene to examine how rhizospheric AMF communities are shaped within the rhizosphere of 11 Salix cultivars introduced across non-contaminated and PHC-contaminated soil. While PHC contamination levels had a strong impact on AMF community structure, Salix planting increased the abundance of several AMF families [80], inferring that AMF, possibly due to opportunistic associations with the plant, are involved in plant adaptation to PHC contamination [34].

Tardif et al. [178] amplified the bacterial 16S rRNA gene and fungal ITS regions using Ion Torrent sequencing in order to characterize the variations between plant compartments (bulk soil, rhizosphere soil, roots, and stems) in the microbiome of two Salix cultivars growing under three PHC contamination levels at a former petrochemical site. PHC contamination was found to be the main factor, shaping not only the rhizosphere but also the root and stem microbiome structure [178]. Additionally, the presence of the plant offered a protective buffer zone against PHC pollution in the rhizosphere and other plant tissues, subsequently minimizing the severe effects of PHC contamination on the microbiome composition, as compared with adjunct bulk soil [178]. Finally, increasing PHC contamination caused a shift in the microbial community composition, favoring beneficial microbiome communities such as putative PHC-degraders and PGPR [178].

In a recent study, Mitter et al. [179] used high-throughput Illumina MiSeq amplicon sequencing of the $16 \mathrm{~S}$ rRNA gene to characterize the bacterial root microbiome associated with annual barley and sweet clover growing in an oil sands reclamation site. Results confirmed that, consistent with previous reports, the rhizosphere compartment produced the strongest differentiation of the root microbiome community structure $[43,179,180]$; for example, Proteobacteria was the predominant phyla in the endosphere microbiome, whereas phyla such as Acidobacteria and Gemmatimonadetes were restricted only to the rhizosphere microbiome [179]. Additionally, host plants play a major role in shaping the 
root microbiome community structure [179], implying plants have the ability to select for specific soil microbiota [179].

\subsection{Metatranscriptomics}

Metatranscriptomics refers to the study of mRNA expression profiles of complex microbial communities within natural environments [181]. Unlike metagenomics, metatranscriptomics can enhance our understanding about how microbiome functions can be altered due to PHC contamination [181]. In the context of phytoremediation, metatranscriptomics has been used to study plant-associated microbial activities in PHC-contaminated soil. For example, in a greenhouse experiment, Yergeau et al. [51] compared the expression of functional genes in the rhizosphere and bulk soil of willow plants growing in contaminated and uncontaminated soil using a metatranscriptomics approach. Combined selective pressure of the pollutants and rhizosphere resulted in an increased expression of genes related to competition, such as antibiotic resistance and biofilm formation, in the contaminated rhizosphere [51]. Additionally, genes related to PHC degradation were more expressed in polluted soils [51].

More recently, Yergeau et al. [67] sequenced the rhizosphere metatranscriptome of four willow species and the plant root metatranscriptome for two willow species growing in PHC-contaminated and non-contaminated soil at a former petroleum refinery site. The abundance of transcripts for many microbial taxa and functions were significantly higher in contaminated rhizosphere soil for Salix eriocephala, S. miyabeana, and S. purpurea, compared to the rhizosphere of $S$. caprea [67]. The root metatranscriptomes of two willow cultivars were compared, showing that plant transcripts were mostly influenced by willow species, while microbial transcripts primarily responded to contamination level [67].

Pagé et al. [182] used a transcriptomics-based approach to identify microbes involved in willow-microbes PHC degradation systems. Enhanced expression of the four genes related to PHC degradation was observed within the bacterial orders Actinomycetales, Rhodospirillales, Burkholderiales, Alteromonadales, Solirubrobacterales, Caulobacterales, and Rhizobiales, implying that members of these microbial taxa are active participants in the willow-microbes association [182]. Information obtained from metatranscriptomics studies on complex systems, such as plants and their associated highly diverse microbial communities, growing in PHC-contaminated soil could help optimize phytoremediation and enhance their use $[51,67,181,182]$.

\subsection{Genome Sequencing}

Due to the decrease in cost and difficulty over the past decade, sequencing, assembly, and annotation of bacterial genomes is becoming a relatively common practice in many fields of microbiology, including environmental microbiology. By sequencing the entire bacterial genome, valuable information can be obtained such as isolate identification, finding important bacterial traits, life style, ecological adaptation, genetic structure, and metabolic pathways.

Over the past few years, many complete and draft genome sequences of bacterial strains, with versatile abilities to degrade PHCs, have been published and are available in public databases [164]. The genome sequences of different PHC-degrading bacterial strains provide structures for sets of genes, operons, and degradative pathways responsible for remediation of PHC-contaminated environments [164]. Some of these bacterial genomes and their importance in rhizoremediation are listed in Table 5.

Zhao et al. [183] reported the complete genome sequence of Sphingobium yanoikuyae strain B1 that has versatile abilities to degrade various PHCs pollutants, such as biphenyl, naphthalene, phenanthrene, toluene, and anthracene. The 5,200,045 bp genome of this bacterium contains 35 dioxygenases or putative dioxygenases genes, including catechol 1,2-dixoygenase, biphenyl 2,3-dioxygenase, and biphenyl-2,3-diol 1,2-dioxygenase [183]. Additionally, the genome of $S$. yanoikuyae strain B1 contains 48 ABC transporter-related genes and 82 TonB-dependent receptors, which may be involved in PAH transporta- 
tion [183]. Such valuable information can provide clues about the genetic versatility of Sphingobium strains and the mechanisms of PAHs biodegradation, which might potentially aid in rhizoremediation applications [183].

Table 5. Recent genomes of bacterial strains capable of degrading PHCs.

\begin{tabular}{|c|c|c|c|c|c|}
\hline Bacterial Strain & $\begin{array}{l}\text { Importance in } \\
\text { Bioremediation }\end{array}$ & Isolation Source & PGPR Features & Genome Size & Reference \\
\hline $\begin{array}{l}\text { Pseudomonas veronii } \\
\text { strain VI4T1 }\end{array}$ & $\begin{array}{c}\text { degradation of aromatic } \\
\text { and aliphatic } \\
\text { hydrocarbons }\end{array}$ & $\begin{array}{l}\text { long-term oil } \\
\text { field-polluted soil }\end{array}$ & IAA, siderophore & $7.15 \mathrm{Mb}$ & [184] \\
\hline $\begin{array}{l}\text { Pseudomonas sp. } \\
\text { strain VI4.1 }\end{array}$ & $\begin{array}{l}\text { degradation of aromatic } \\
\text { and aliphatic } \\
\text { hydrocarbons }\end{array}$ & $\begin{array}{l}\text { long-term oil } \\
\text { field-polluted soil }\end{array}$ & IAA, siderophore & $7.3 \mathrm{Mb}$ & [184] \\
\hline $\begin{array}{l}\text { Halomonas sp. } \\
\text { strain G11 }\end{array}$ & $\begin{array}{l}\text { degradation of alkanes } \\
\text { and polyaromatic } \\
\text { hydrocarbons }\end{array}$ & $\begin{array}{l}\text { hypersaline } \\
\text { sediment }\end{array}$ & $\begin{array}{l}\text { Salt-tolerance, } \\
\text { biosurfactant } \\
\text { production }\end{array}$ & $3.96 \mathrm{Mb}$ & [185] \\
\hline $\begin{array}{l}\text { Pseudomonas aeruginosa } \\
\text { strain DN1 }\end{array}$ & $\begin{array}{l}\text { fluoranthene } \\
\text { degradation }\end{array}$ & $\begin{array}{l}\text { PHC-contaminated } \\
\text { soil }\end{array}$ & N/D & $6.6 \mathrm{Mb}$ & [186] \\
\hline $\begin{array}{c}\text { Alcaligenes aquatilis } \\
\text { strain } \\
\text { BU33N }\end{array}$ & $\begin{array}{l}\text { degradation of } n \text {-alkanes } \\
\text { and phenanthrene }\end{array}$ & $\begin{array}{l}\text { PHC-polluted } \\
\text { sediments }\end{array}$ & $\begin{array}{l}\text { biosurfactant } \\
\text { production; heavy } \\
\text { metals resistance }\end{array}$ & $3.8 \mathrm{Mb}$ & [187] \\
\hline $\begin{array}{l}\text { Gordonia paraffinivorans } \\
\text { strain MTZ052 }\end{array}$ & $\begin{array}{l}\text { degradation of } \\
n \text {-hexadecane }\end{array}$ & composting pile & $\mathrm{N} / \mathrm{D}$ & $4.8 \mathrm{Mb}$ & [188] \\
\hline $\begin{array}{c}\text { Gordonia sihwensis } \\
\text { strain } \\
\text { MTZ096 }\end{array}$ & $\begin{array}{l}\text { degradation of } \\
n \text {-hexadecane }\end{array}$ & composting pile & $\mathrm{N} / \mathrm{D}$ & $3.9 \mathrm{Mb}$ & [188] \\
\hline $\begin{array}{c}\text { Klebsiella pneumoniae } \\
\text { strain } \\
\text { AWD5 }\end{array}$ & $\begin{array}{c}\text { degradation of } \\
\text { xenobiotic compounds }\end{array}$ & $\begin{array}{l}\text { PAH-contaminated } \\
\text { soil }\end{array}$ & $\begin{array}{l}\text { siderophore } \\
\text { production }\end{array}$ & $4.8 \mathrm{Mb}$ & [189] \\
\hline $\begin{array}{l}\text { Bacillus licheniformis } \\
\text { strain VSD4 }\end{array}$ & $\begin{array}{l}\text { degradation of diesel } \\
\text { fuel }\end{array}$ & $\begin{array}{l}\text { leaves of Hedera helix } \\
\text { plants growing at a } \\
\text { high-traffic } \\
\text { city center }\end{array}$ & IAA, siderophore & $4.19 \mathrm{Mb}$ & [190] \\
\hline $\begin{array}{l}\text { Pseudomonas putida } \\
\text { strain BS3701 }\end{array}$ & $\begin{array}{c}\text { degradation of crude oil } \\
\text { and PAHs }\end{array}$ & $\begin{array}{l}\text { soil contaminated } \\
\text { with coke } \\
\text { by-product waste }\end{array}$ & $\mathrm{N} / \mathrm{D}$ & $6.3 \mathrm{Mb}$ & [191] \\
\hline
\end{tabular}

\section{Concluding Remarks and Future Perspectives}

In spite of the remarkable progress detailed above, rhizoremediation remains a marginal choice for in situ soil decontamination. Given the important role of the rhizosphere microbiome in phytoremediation, future efforts to optimize this technology should include (i) selection of the right plant host, which can alter the function of the rhizosphere microbiome to benefit rhizoremediation activities. Special emphasis should be placed on selecting native plants that show tolerance toward PHCs. Using such plants could offer economic and environmentally sustainable solutions to remediate PHC-contaminated soil. (ii) Modern microbial ecology omics-tools should be used not only to better understand the structure and function of the rhizosphere microbiome associated with plants but also to recommend more efficient management strategies and predict the clean-up time of rhizoremediation. (iii) The effect of novel microbiome inocula combining PGPR and hydrocarbon-degrading bacteria should be tested under large-scale field experiments. (iv) The complicity of the rhizosphere environment and the influence of many biotic and abiotic factors on the composition and function of rhizosphere microbiome should be taken into account, which might subsequently affect rhizoremediation efficiency. Therefore, it 
would be important to characterize biotic and abiotic parameters in PHC-contaminated sites prior to application of rhizoremediation strategies.

Author Contributions: Writing, F.A., M.H. and M.S.-A. supervised the work, and edited, and revised the manuscript draft. All authors have read and agreed to the published version of the manuscript.

Funding: We acknowledge funding for this work by the GenoRem Project, which is primarily financed by Genome Canada and Genome Quebec, and by NSERC discovery grants to M.S.-A. and M.H., F.A. was also supported by a grant from King Saud University. The GenoRem project contains several industrial partners, but these partners have in no way influenced or modified this manuscript.

Conflicts of Interest: The authors declare no conflict of interest.

\section{References}

1. Brzeszcz, J.; Kaszycki, P. Aerobic bacteria degrading both n-alkanes and aromatic hydrocarbons: An undervalued strategy for metabolic diversity and flexibility. Biodegradation 2018, 29, 359-407. [CrossRef]

2. Gkorezis, P.; Daghio, M.; Franzetti, A.; Van Hamme, J.; Sillen, W.; Vangronsveld, J. The Interaction between Plants and Bacteria in the Remediation of Petroleum Hydrocarbons: An Environmental Perspective. Front. Microbiol. 2016, 7, 1836. [CrossRef] [PubMed]

3. Wang, Z.; Fingas, M.; Yang, C.; Christensen, J.H. Crude Oil and Refined Product Fingerprinting: Principles. In Environmental Forensics: Contaminant Specific Guide; Morrison, R.D., Murphy, B.L., Eds.; Academic Press: New York, NY, USA, 2006 ; pp. 339-407.

4. Farrell-Jones, J. Petroleum Hydrocarbons and Polyaromatic Hydrocarbons; Blackwell Publishing CRC Press: New York, NY, USA, 2003.

5. Tissot, B.P.; Welte, D.H. Petroleum Formation and Occurrence; Springer Science \& Business Media: Berlin/Heidelberg, Germany, 2013.

6. Pandey, P.; Pathak, H.; Dave, S. Microbial Ecology of Hydrocarbon Degradation in the Soil: A Review. Res. J. Environ. Toxicol. 2016, 10, 1-15. [CrossRef]

7. Hoang, S.A.; Lamb, D.; Seshadri, B.; Sarkar, B.; Choppala, G.; Kirkham, M.; Bolan, N.S. Rhizoremediation as a green technology for the remediation of petroleum hydrocarbon-contaminated soils. J. Hazard. Mater. 2020, 401, 123282. [CrossRef] [PubMed]

8. Secretariat. Federal Contaminated Sites Inventory. Available online: https://www.tbs-sct.gc.ca/fcsi-rscf/home-accueil-eng.aspx (accessed on 18 August 2020).

9. Panagos, P.; Van Liedekerke, M.; Yigini, Y.; Montanarella, L. Contaminated Sites in Europe: Review of the Current Situation Based on Data Collected through a European Network. J. Environ. Public Health 2013, 2013, 1-11. [CrossRef] [PubMed]

10. Henner, P.; Schiavon, M.; Morel, J.-L.; Lichtfouse, E. Polycyclic aromatic hydrocarbon (PAH) occurrence and remediation methods. Analusis 1997, 25, M56-M59.

11. Inoue, Y.; Katayama, A. Two-scale evaluation of remediation technologies for a contaminated site by applying economic inputoutput life cycle assessment: Risk-cost, risk-energy consumption and risk- $\mathrm{CO}_{2}$ emission. J. Hazard. Mater. 2011, 192, 1234-1242. [CrossRef] [PubMed]

12. Yerushalmi, L.; Rocheleau, S.; Cimpoia, R.; Sarrazin, M.; Sunahara, G.; Peisajovich, A.; Leclair, G.; Guiot, S.R. Enhanced biodegradation of petroleum hydrocarbons in contaminated soil. J. Soil Contam. 1998, 7, 37-51. [CrossRef]

13. Pilon-Smits, E. Phytoremediation. Annu. Rev. Plant Biol. 2005, 56, 15-39. [CrossRef]

14. Salt, D.E.; Smith, R.D.; Raskin, I. Phytoremediation. Annu. Rev. Plant Biol. 1998, 49, 643-668. [CrossRef]

15. Aken, B.V.; Doty, S.L. Transgenic plants and associated bacteria for phytoremediation of chlorinated compounds. Biotechnol. Genet. Eng. Rev. 2009, 26, 43-64. [CrossRef]

16. Panz, K.; Miksch, K. Phytoremediation of explosives (TNT, RDX, HMX) by wild-type and transgenic plants. J. Environ. Manag. 2012, 113, 85-92. [CrossRef] [PubMed]

17. Leguizamo, M.A.O.; Gómez, W.D.F.; Sarmiento, M.C.G. Native herbaceous plant species with potential use in phytoremediation of heavy metals, spotlight on wetlands-A review. Chemosphere 2017, 168, 1230-1247. [CrossRef] [PubMed]

18. Ch, J.A.J.; Romero, R.M. Evaluation of Cajanus cajan (pigeon pea) for phytoremediation of landfill leachate containing chromium and lead. Int. J. Phytoremediat. 2016, 18, 1122-1127. [CrossRef]

19. Olette, R.; Couderchet, M.; Biagianti, S.; Eullaffroy, P. Toxicity and removal of pesticides by selected aquatic plants. Chemosphere 2008, 70, 1414-1421. [CrossRef]

20. Newman, L.A.; Reynolds, C.M. Phytodegradation of organic compounds. Curr. Opin. Biotechnol. 2004, 15, 225-230. [CrossRef]

21. Sharma, S.; Singh, B.; Manchanda, V.K. Phytoremediation: Role of terrestrial plants and aquatic macrophytes in the remediation of radionuclides and heavy metal contaminated soil and water. Environ. Sci. Pollut. Res. 2014, 22, 946-962. [CrossRef]

22. Devi, S.; Nandwal, A.; Angrish, R.; Arya, S.; Kumar, N.; Sharma, S. Phytoremediation potential of some halophytic species for soil salinity. Int. J. Phytoremediat. 2015, 18, 693-696. [CrossRef] [PubMed]

23. Transparency Market Research. BioremediationI Technology \& Services Market to Reach Valuation gf $\sim$ US\$ 20 BN by 2030. Available online: https://www.transparencymarketresearch.com/pressrelease/bioremediation-technology-services-market.htm (accessed on 18 September 2020). 
24. Mench, M.; Lepp, N.; Bert, V.; Schwitzguébel, J.-P.; Gawroński, S.; Schröder, P.; Vangronsveld, J. Successes and limitations of phytotechnologies at field scale: Outcomes, assessment and outlook from COST Action 859. J. Soils Sediments 2010, 10, 1039-1070. [CrossRef]

25. Vangronsveld, J.; Herzig, R.; Weyens, N.; Boulet, J.; Adriaensen, K.; Ruttens, A.; Thewys, T.; Vassilev, A.; Meers, E.; Nehnevajova, E.; et al. Phytoremediation of contaminated soils and groundwater: Lessons from the field. Environ. Sci. Pollut. Res. 2009, 16, 765-794. [CrossRef] [PubMed]

26. Arthur, E.L.; Rice, P.J.; Rice, P.J.; Anderson, T.A.; Baladi, S.M.; Henderson, K.L.; Coats, J.R. Phytoremediation-An overview. Crit. Rev. Plant Sci. 2005, 24, 109-122. [CrossRef]

27. Wenzel, W.W. Rhizosphere processes and management in plant-assisted bioremediation (phytoremediation) of soils. Plant Soil 2008, 321, 385-408. [CrossRef]

28. Kuiper, I.; Lagendijk, E.L.; Bloemberg, G.V.; Lugtenberg, B.J.J. Rhizoremediation: A Beneficial Plant-Microbe Interaction. Mol. Plant-Microbe Interact. 2004, 17, 6-15. [CrossRef] [PubMed]

29. Ali, H.; Khan, E.; Sajad, M.A. Phytoremediation of heavy metals-Concepts and applications. Chemosphere 2013, 91, 869-881. [CrossRef]

30. Behera, K.K. Phytoremediation, transgenic plants and microbes. In Sustainable Agriculture Reviews; Springer: Berlin/Heidelberg, Germany, 2014; pp. 65-85.

31. Anderson, T.A.; Guthrie, E.A.; Walton, B.T. Bioremediation in the rhizosphere. Environ. Sci. Technol. 1993, 27, 2630-2636. [CrossRef]

32. Martin, B.; George, S.J.; Price, C.A.; Ryan, M.; Tibbett, M. The role of root exuded low molecular weight organic anions in facilitating petroleum hydrocarbon degradation: Current knowledge and future directions. Sci. Total Environ. 2014, 472, 642-653. [CrossRef]

33. Correa-García, S.; Pande, P.; Séguin, A.; St-Arnaud, M.; Yergeau, E. Rhizoremediation of petroleum hydrocarbons: A model system for plant microbiome manipulation. Microb. Biotechnol. 2018, 11, 819-832. [CrossRef]

34. Ethijs, S.; Sillen, W.; Erineau, F.; Eweyens, N.; Vangronsveld, J. Towards an Enhanced Understanding of Plant-Microbiome Interactions to Improve Phytoremediation: Engineering the Metaorganism. Front. Microbiol. 2016, 7, 341. [CrossRef]

35. Philippot, L.; Raaijmakers, J.; Lemanceau, P.; van der Putten, W. Going back to the roots: The microbial ecology of the rhizosphere. Nat. Rev. Genet. 2013, 11, 789-799. [CrossRef]

36. Raaijmakers, J.M.; Paulitz, T.; Steinberg, C.; Alabouvette, C.; Moënne-Loccoz, Y. The rhizosphere: A playground and battlefield for soilborne pathogens and beneficial microorganisms. Plant Soil 2008, 321, 341-361. [CrossRef]

37. Berendsen, R.L.; Pieterse, C.; Bakker, P.A. The rhizosphere microbiome and plant health. Trends Plant Sci. 2012, 17, 478-486. [CrossRef] [PubMed]

38. Berg, G.; Smalla, K. Plant species and soil type cooperatively shape the structure and function of microbial communities in the rhizosphere. FEMS Microbiol. Ecol. 2009, 68, 1-13. [CrossRef] [PubMed]

39. Bakker, P.A.H.M.; Berendsen, R.L.; Doornbos, R.F.; Wintermans, P.C.A.; Pieterse, C.M.J. The rhizosphere revisited: Root microbiomics. Front. Plant Sci. 2013, 4, 165. [CrossRef]

40. Kuzyakov, Y.; Blagodatskaya, E. Microbial hotspots and hot moments in soil: Concept \& review. Soil Biol. Biochem. 2015, 83, 184-199. [CrossRef]

41. Smalla, K.; Wieland, G.; Buchner, A.; Zock, A.; Parzy, J.; Kaiser, S.; Roskot, N.; Heuer, H.; Berg, G. Bulk and Rhizosphere Soil Bacterial Communities Studied by Denaturing Gradient Gel Electrophoresis: Plant-Dependent Enrichment and Seasonal Shifts Revealed. Appl. Environ. Microbiol. 2001, 67, 4742-4751. [CrossRef]

42. Loeppmann, S.; Blagodatskaya, E.; Pausch, J.; Kuzyakov, Y. Substrate quality affects kinetics and catalytic efficiency of exoenzymes in rhizosphere and detritusphere. Soil Biol. Biochem. 2016, 92, 111-118. [CrossRef]

43. Bulgarelli, D.; Rott, M.; Schlaeppi, K.; Van Themaat, E.V.L.; Ahmadinejad, N.; Assenza, F.; Rauf, P.; Huettel, B.; Reinhardt, R.; Schmelzer, E.; et al. Revealing structure and assembly cues for Arabidopsis root-inhabiting bacterial microbiota. Nat. Cell Biol. 2012, 488, 91-95. [CrossRef]

44. Lundberg, D.S.; Lebeis, S.L.; Paredes, S.H.; Yourstone, S.; Gehring, J.; Malfatti, S.; Tremblay, J.; Engelbrektson, A.; Kunin, V.; Del Rio, T.G.; et al. Defining the core Arabidopsis thaliana root microbiome. Nat. Cell Biol. 2012, 488, 86-90. [CrossRef] [PubMed]

45. Vieira, S.; Sikorski, J.; Dietz, S.; Herz, K.; Schrumpf, M.; Bruelheide, H.; Scheel, D.; Friedrich, M.W.; Overmann, J. Drivers of the composition of active rhizosphere bacterial communities in temperate grasslands. ISME J. 2019, 14, 463-475. [CrossRef]

46. Vives-Peris, V.; de Ollas, C.; Gómez-Cadenas, A.; Pérez-Clemente, R.M. Root exudates: From plant to rhizosphere and beyond. Plant Cell Rep. 2019, 39, 3-17. [CrossRef]

47. Rohrbacher, F.; St-Arnaud, M. Root Exudation: The Ecological Driver of Hydrocarbon Rhizoremediation. Agronomy 2016, 6, 19. [CrossRef]

48. Jones, D.; Murphy, D. Microbial response time to sugar and amino acid additions to soil. Soil Biol. Biochem. 2007, 39, 2178-2182. [CrossRef]

49. Gao, Y.; Yang, Y.; Ling, W.; Kong, H.; Zhu, X. Gradient Distribution of Root Exudates and Polycyclic Aromatic Hydrocarbons in Rhizosphere Soil. Soil Sci. Soc. Am. J. 2011, 75, 1694-1703. [CrossRef]

50. Muratova, A.; Dubrovskaya, E.; Golubev, S.; Grinev, V.; Chernyshova, M.; Turkovskaya, O. The coupling of the plant and microbial catabolisms of phenanthrene in the rhizosphere of Medicago sativa. J. Plant Physiol. 2015, 188, 1-8. [CrossRef] 
51. Yergeau, E.; Sanschagrin, S.; Maynard, C.; St-Arnaud, M.; Greer, C.W. Microbial expression profiles in the rhizosphere of willows depend on soil contamination. ISME J. 2013, 8, 344-358. [CrossRef] [PubMed]

52. Gao, Y.; Ren, L.; Ling, W.; Gong, S.; Sun, B.; Zhang, Y. Desorption of phenanthrene and pyrene in soils by root exudates. Bioresour. Technol. 2010, 101, 1159-1165. [CrossRef]

53. Van Elsas, J.D.; Bailey, M.J. The ecology of transfer of mobile genetic elements. FEMS Microbiol. Ecol. 2002, 42, 187-197. [CrossRef]

54. Top, E.M.; Springael, D. The role of mobile genetic elements in bacterial adaptation to xenobiotic organic compounds. Curr. Opin. Biotechnol. 2003, 14, 262-269. [CrossRef]

55. Sentchilo, V.; Mayer, A.P.; Guy, L.; Miyazaki, R.; Tringe, S.; Barry, K.; Malfatti, S.; Goessmann, A.; Robinson-Rechavi, M.; van der Meer, J.R. Community-wide plasmid gene mobilization and selection. ISME J. 2013, 7, 1173-1186. [CrossRef]

56. Khan, S.; Afzal, M.; Iqbal, S.; Khan, Q.M. Plant-bacteria partnerships for the remediation of hydrocarbon contaminated soils Chemosphere 2013, 90, 1317-1332. [CrossRef] [PubMed]

57. Chaudhry, Q.; Blom-Zandstra, M.; Gupta, S.K.; Joner, E.J. Utilising the Synergy between Plants and Rhizosphere Microorganisms to Enhance Breakdown of Organic Pollutants in the Environment (15 pp). Environ. Sci. Pollut. Res. 2004, 12, 34-48. [CrossRef] [PubMed]

58. Aprill, W.; Sims, R.C. Evaluation of the use of prairie grasses for stimulating polycyclic aromatic hydrocarbon treatment in soil. Chemosphere 1990, 20, 253-265. [CrossRef]

59. Gaskin, S.E.; Bentham, R.H. Rhizoremediation of hydrocarbon contaminated soil using Australian native grasses. Sci. Total Environ. 2010, 408, 3683-3688. [CrossRef]

60. Hall, J.; Soole, K.; Bentham, R. Hydrocarbon Phytoremediation in the FamilyFabacea-A Review. Int. J. Phytoremediat. 2011, 13, 317-332. [CrossRef]

61. Reynolds, C.M.; Wolf, D.C.; Gentry, T.J.; Perry, L.B.; Pidgeon, C.S.; Koenen, B.A.; Rogers, H.B.; Beyrouty, C.A. Plant enhancement of indigenous soil micro-organisms: A low-cost treatment of contaminated soils. Polar Rec. 1999, 35, 33-40. [CrossRef]

62. Frick, C.; Germida, J.; Farrell, R. Assessment of phytoremediation as an in-situ technique for cleaning oil-contaminated sites. In Proceedings of the Technical Seminar on Chemical Spills, Caligary, AB, Canada, 31 May-1 June 1999; pp. 105a-124a.

63. Lu, M.; Zhang, Z.; Sun, S.; Wei, X.; Wang, Q.; Su, Y. The Use of Goosegrass (Eleusine indica) to Remediate Soil Contaminated with Petroleum. Water Air Soil Pollut. 2009, 209, 181-189. [CrossRef]

64. Kuzovkina, Y.A.; Volk, T.A. The characterization of willow (Salix L.) varieties for use in ecological engineering applications: Co-ordination of structure, function and autecology. Ecol. Eng. 2009, 35, 1178-1189. [CrossRef]

65. Bell, T.; Hassan, S.E.-D.; Lauron-Moreau, A.; Al-Otaibi, F.; Hijri, M.; Yergeau, E.; St-Arnaud, M. Linkage between bacterial and fungal rhizosphere communities in hydrocarbon-contaminated soils is related to plant phylogeny. ISME J. 2013, 8, 331-343. [CrossRef] [PubMed]

66. de Cárcer, D.A.; Martín, M.; Karlson, U.; Rivilla, R. Changes in Bacterial Populations and in Biphenyl Dioxygenase Gene Diversity in a Polychlorinated Biphenyl-Polluted Soil after Introduction of Willow Trees for Rhizoremediation. Appl. Environ. Microbiol. 2007, 73, 6224-6232. [CrossRef] [PubMed]

67. Yergeau, E.; Tremblay, J.; Joly, S.; Labrecque, M.; Maynard, C.; Pitre, F.E.; St-Arnaud, M.; Greer, C.W. Soil contamination alters the willow root and rhizosphere metatranscriptome and the root-rhizosphere interactome. ISME J. 2018, 12, 869-884. [CrossRef] [PubMed]

68. Pérez-Jaramillo, J.E.; Mendes, R.; Raaijmakers, J.M. Impact of plant domestication on rhizosphere microbiome assembly and functions. Plant Mol. Biol. 2015, 90, 635-644. [CrossRef]

69. Timmis, K.N.; Pieper, D.H. Bacteria designed for bioremediation. Trends Biotechnol. 1999, 17, 201-204. [CrossRef]

70. Brown, R.W. Revegetation of an Alpine Mine disturbance: Beartooth Plateau, Montana; US Department of Agriculture; Forest Service, Intermountain Forest \& Range: Logan, Utah, 1976; Volume 206.

71. Desjardins, D.; Nissim, W.G.; Pitre, F.E.; Naud, A.; Labrecque, M. Distribution patterns of spontaneous vegetation and pollution at a former decantation basin in southern Québec, Canada. Ecol. Eng. 2014, 64, 385-390. [CrossRef]

72. Lee, S.-J.; Kong, M.; St-Arnaud, M.; Hijri, M. Arbuscular Mycorrhizal Fungal Communities of Native Plant Species under High Petroleum Hydrocarbon Contamination Highlights Rhizophagus as a Key Tolerant Genus. Microorganisms 2020, 8, 872. [CrossRef] [PubMed]

73. Brundrett, M. Mycorrhizas in natural ecosystems. Adv. Ecol. Res. 1991, 21, 171-313.

74. Bolduc, A.R.; Hijri, M. The Use of Mycorrhizae to Enhance Phosphorus Uptake: A Way Out the Phosphorus Crisis. J. Fertil. Pestic. 2011, 2, 1-5. [CrossRef]

75. Miransari, M. Hyperaccumulators, arbuscular mycorrhizal fungi and stress of heavy metals. Biotechnol. Adv. 2011, 29, 645-653. [CrossRef] [PubMed]

76. Porcel, R.; Aroca, R.; Lozano, J.M.R. Salinity stress alleviation using arbuscular mycorrhizal fungi. A review. Agron. Sustain. Dev. 2011, 32, 181-200. [CrossRef]

77. Smith, S.E.; Read, D.J. Mycorrhizal Symbiosis; Academic Press: New York, NY, USA, 2008.

78. St-Arnaud, M.; Vujanovic, V. Effects of the Arbuscular Mycorrhizal Symbiosis on Plant Diseases and Pests. In Mycorrhizae in Crop Production; Hamel, C., Plenchette, C., Eds.; CRC Press: London, UK, 2007; pp. 67-123.

79. Hassan, S.E.; Hijri, M.; St-Arnaud, M. Effect of arbuscular mycorrhizal fungi on trace metal uptake by sunflower plants grown on cadmium contaminated soil. New Biotechnol. 2013, 30, 780-787. [CrossRef] 
80. Hassan, S.E.-D.; Bell, T.H.; Stefani, F.O.P.; Denis, D.; Hijri, M.; St-Arnaud, M. Contrasting the Community Structure of Arbuscular Mycorrhizal Fungi from Hydrocarbon-Contaminated and Uncontaminated Soils following Willow (Salix spp. L.) Planting. PLoS ONE 2014, 9, e102838. [CrossRef]

81. Reichenauer, T.G.; Germida, J. Phytoremediation of Organic Contaminants in Soil and Groundwater. ChemSusChem 2008, 1, 708-717. [CrossRef]

82. Sandermann, H. Plant metabolism of xenobiotics. Trends Biochem. Sci. 1992, 17, 82-84. [CrossRef]

83. Singer, A.C. Advances in development of transgenic plants for remediation of xenobiotic pollutants. In Phytoremediation and Rhizoremediation: Theoretical Background; Mackova, M., Dowling, D., Macek, T., Eds.; Springer: Dordrecht, UK, 2006 ; pp. 5-21.

84. Glick, B.R.; Stearns, J.C. Making Phytoremediation Work Better: Maximizing a Plant's Growth Potential in the Midst of Adversity. Int. J. Phytoremediat. 2011, 13, 4-16. [CrossRef]

85. Hardoim, P.; van Overbeek, L.S.; van Elsas, J.D. Properties of bacterial endophytes and their proposed role in plant growth. Trends Microbiol. 2008, 16, 463-471. [CrossRef] [PubMed]

86. Rughöft, S.; Herrmann, M.; Lazar, C.; Cesarz, S.; Levick, S.; Trumbore, S.E.; Küsel, K. Community Composition and Abundance of Bacterial, Archaeal and Nitrifying Populations in Savanna Soils on Contrasting Bedrock Material in Kruger National Park, South Africa. Front. Microbiol. 2016, 7, 1638. [CrossRef]

87. Richardson, A.E.; Barea, J.M.; McNeill, A.M.; Prigent-Combaret, C. Acquisition of phosphorus and nitrogen in the rhizosphere and plant growth promotion by microorganisms. Plant Soil 2009, 321, 305-339. [CrossRef]

88. Schlaeppi, K.; Bulgarelli, D. The Plant Microbiome at Work. Mol. Plant-Microbe Interact. 2015, 28, 212-217. [CrossRef] [PubMed]

89. Vessey, J.K. Plant growth promoting rhizobacteria as biofertilizers. Plant Soil 2003, 255, 571-586. [CrossRef]

90. Bloemberg, G.V.; Lugtenberg, B.J. Molecular basis of plant growth promotion and biocontrol by rhizobacteria. Curr. Opin. Plant Biol. 2001, 4, 343-350. [CrossRef]

91. Haas, D.; Défago, G. Biological control of soil-borne pathogens by fluorescent pseudomonads. Nat. Rev. Genet. 2005, 3, 307-319. [CrossRef]

92. Lugtenberg, B.; Kamilova, F. Plant-Growth-Promoting Rhizobacteria. Annu. Rev. Microbiol. 2009, 63, 541-556. [CrossRef]

93. Stevens, C.J. Nitrogen in the environment. Science 2019, 363, 578-580. [CrossRef] [PubMed]

94. Boddey, R.M.; De Oliveira, O.; Urquiaga, S.; Reis, V.; De Olivares, F.; Baldani, V.; Döbereiner, J. Biological nitrogen fixation associated with sugar cane and rice: Contributions and prospects for improvement. In Management of Biological Nitrogen Fixation for the Development of More Productive and Sustainable Agricultural Systems; Springer: Berlin/Heidelberg, Germany, 1995; pp. 195-209.

95. Dobbelaere, S.; Vanderleyden, J.; Okon, Y. Plant Growth-Promoting Effects of Diazotrophs in the Rhizosphere. Crit. Rev. Plant Sci. 2003, 22, 107-149. [CrossRef]

96. Sessitsch, A.; Howieson, J.; Perret, X.; Antoun, H.; Martinez-Romero, E. Advances in Rhizobium research. Crit. Rev. Plant Sci. 2002, 21, 323-378. [CrossRef]

97. Alori, E.T.; Glick, B.R.; Babalola, O.O. Microbial Phosphorus Solubilization and Its Potential for Use in Sustainable Agriculture. Front. Microbiol. 2017, 8, 971. [CrossRef] [PubMed]

98. Stevenson, F.J.; Cole, M.A. Cycles of Soils: Carbon, Nitrogen, Phosphorus, Sulfur, Micronutrients, 2nd ed.; John Wiley \& Sons: New York, NY, USA, 1999.

99. Glass, A.D. Plant Mineral Nutrition. An Introduction to Current Concepts; Jones and Bartlett Publishers, Inc.: Burlington, MA, USA, 1989.

100. Kim, K.Y.; Jordan, D.; McDonald, G.A. Effect of phosphate-solubilizing bacteria and vesicular-arbuscular mycorrhizae on tomato growth and soil microbial activity. Biol. Fertil. Soils 1997, 26, 79-87. [CrossRef]

101. Rodríguez, H.; Fraga, R. Phosphate solubilizing bacteria and their role in plant growth promotion. Biotechnol. Adv. 1999, 17, 319-339. [CrossRef]

102. Sharma, S.B.; Sayyed, R.; Trivedi, M.H.; Gobi, T.A. Phosphate solubilizing microbes: Sustainable approach for managing phosphorus deficiency in agricultural soils. SpringerPlus 2013, 2, 1-14. [CrossRef]

103. Jorquera, M.A.; Crowley, D.E.; Marschner, P.; Greiner, R.; Fernández, M.T.; Romero, D.; Blackburn, D.; Mora, M.L. Identification of $\beta$-propeller phytase-encoding genes in culturable Paenibacillus and Bacillus spp. from the rhizosphere of pasture plants on volcanic soils. FEMS Microbiol. Ecol. 2010, 75, 163-172. [CrossRef]

104. Zhang, X.; Zhang, D.; Sun, W.; Wang, T. The Adaptive Mechanism of Plants to Iron Deficiency via Iron Uptake, Transport, and Homeostasis. Int. J. Mol. Sci. 2019, 20, 2424. [CrossRef]

105. Crowley, D.E.; Kraemer, S.M. Function of siderophores in the plant rhizosphere. In The Rhizosphere, Biochemistry and Organic Substances at the Soil-Plant Interface; CRC Press: Boca Raton, FL, USA, 2007; pp. 73-109.

106. Rajkumar, M.; Ae, N.; Prasad, M.N.V.; Freitas, H. Potential of siderophore-producing bacteria for improving heavy metal phytoextraction. Trends Biotechnol. 2010, 28, 142-149. [CrossRef] [PubMed]

107. Sessitsch, A.; Kuffner, M.; Kidd, P.; Vangronsveld, J.; Wenzel, W.W.; Fallmann, K.; Puschenreiter, M. The role of plant-associated bacteria in the mobilization and phytoextraction of trace elements in contaminated soils. Soil Biol. Biochem. 2013, 60, 182-194. [CrossRef] [PubMed]

108. Gururani, M.; Upadhyaya, C.P.; Baskar, V.; Venkatesh, J.; Nookaraju, A.; Park, S.W. Plant Growth-Promoting Rhizobacteria Enhance Abiotic Stress Tolerance in Solanum tuberosum Through Inducing Changes in the Expression of ROS-Scavenging Enzymes and Improved Photosynthetic Performance. J. Plant Growth Regul. 2012, 32, 245-258. [CrossRef] 
109. Sharma, A.; Johri, B.; Glick, B. Plant growth-promoting bacterium Pseudomonas sp. strain GRP3 influences iron acquisition in mung bean (Vigna radiata L. Wilzeck). Soil Biol. Biochem. 2003, 35, 887-894. [CrossRef]

110. Dos Santos, R.M.; Diaz, P.A.E.; Lobo, L.L.B.; Rigobelo, E.C. Use of Plant Growth-Promoting Rhizobacteria in Maize and Sugarcane: Characteristics and Applications. Front. Sustain. Food Syst. 2020, 4, 136. [CrossRef]

111. Mitter, E.K.; Tosi, M.; Obregón, D.; Dunfield, K.E.; Germida, J.J. Rethinking Crop Nutrition in Times of Modern Microbiology: Innovative Biofertilizer Technologies. Front. Sustain. Food Syst. 2021, 5, 29. [CrossRef]

112. McSteen, P. Auxin and Monocot Development. Cold Spring Harb. Perspect. Biol. 2010, 2, a001479. [CrossRef]

113. Salisbury, F.B. The role of plant hormones. In Plant_Environment Interactions; Wilkinson, R.E., Ed.; Marcel Dekker: New York, NY, USA, 1994; pp. 39-81.

114. Martínez, C.; Espinosa-Ruiz, A.; Prat, S. Gibberellins and plant vegetative growth. Annu. Plant Rev. Online 2018, 49, 285-322.

115. Shu, K.; Zhou, W.; Chen, F.; Luo, X.; Yang, W. Abscisic Acid and Gibberellins Antagonistically Mediate Plant Development and Abiotic Stress Responses. Front. Plant Sci. 2018, 9, 416. [CrossRef]

116. Abts, W.; Vandenbussche, B.; De Proft, M.P.; Van De Poel, B. The Role of Auxin-Ethylene Crosstalk in Orchestrating Primary Root Elongation in Sugar Beet. Front. Plant Sci. 2017, 8, 444. [CrossRef]

117. Weyens, N.; van der Lelie, D.; Taghavi, S.; Newman, L.; Vangronsveld, J. Exploiting plant-microbe partnerships to improve biomass production and remediation. Trends Biotechnol. 2009, 27, 591-598. [CrossRef]

118. Patten, C.L.; Glick, B.R. Bacterial biosynthesis of indole-3-acetic acid. Can. J. Microbiol. 1996, 42, 207-220. [CrossRef]

119. Vacheron, J.; Desbrosses, G.; Bouffaud, M.-L.; Touraine, B.; Moënne-Loccoz, Y.; Muller, D.; Legendre, L.; Wisniewski-Dyé, F.; Prigent-Combaret, C. Plant growth-promoting rhizobacteria and root system functioning. Front. Plant Sci. 2013, 4, 356. [CrossRef]

120. Li, J.; Sun, J.; Yang, Y.; Guo, S.; Glick, B.R. Identification of hypoxic-responsive proteins in cucumber roots using a proteomic approach. Plant Physiol. Biochem. 2012, 51, 74-80. [CrossRef] [PubMed]

121. Li, Q.; Saleh-Lakha, S.; Glick, B.R. The effect of native and ACC deaminase-containing Azospirillum brasilense Cd1843 on the rooting of carnation cuttings. Can. J. Microbiol. 2005, 51, 511-514. [CrossRef] [PubMed]

122. Glick, B.R. Modulation of plant ethylene levels by the bacterial enzyme ACC deaminase. FEMS Microbiol. Lett. 2005, $251,1-7$. [CrossRef] [PubMed]

123. Sandhya, V.; Ali, S.Z.; Grover, M.; Reddy, G.; Venkateswarlu, B. Effect of plant growth promoting Pseudomonas spp. on compatible solutes, antioxidant status and plant growth of maize under drought stress. Plant Growth Regul. 2010, 62, 21-30. [CrossRef]

124. Ali, S.; Kim, W.-C. Plant Growth Promotion Under Water: Decrease of Waterlogging-Induced ACC and Ethylene Levels by ACC Deaminase-Producing Bacteria. Front. Microbiol. 2018, 9, 1096. [CrossRef] [PubMed]

125. Mayak, S.; Tirosh, T.; Glick, B.R. Plant growth-promoting bacteria confer resistance in tomato plants to salt stress. Plant Physiol. Biochem. 2004, 42, 565-572. [CrossRef] [PubMed]

126. Belimov, A.A.; Safronova, V.I.; Sergeyeva, T.A.; Egorova, T.N.; Matveyeva, V.A.; Tsyganov, V.E.; Borisov, A.Y.; Tikhonovich, I.A.; Kluge, C.; Preisfeld, A.; et al. Characterization of plant growth promoting rhizobacteria isolated from polluted soils and containing 1-aminocyclopropane-1-carboxylate deaminase. Can. J. Microbiol. 2001, 47, 642-652. [CrossRef] [PubMed]

127. Backer, R.; Rokem, J.S.; Ilangumaran, G.; Lamont, J.; Praslickova, D.; Ricci, E.; Subramanian, S.; Smith, D.L. Plant GrowthPromoting Rhizobacteria: Context, Mechanisms of Action, and Roadmap to Commercialization of Biostimulants for Sustainable Agriculture. Front. Plant Sci. 2018, 9, 1473. [CrossRef] [PubMed]

128. Bashan, Y.; De-Bashan, L.E.; Prabhu, S.R.; Hernandez, J. Advances in plant growth-promoting bacterial inoculant technology: Formulations and practical perspectives (1998-2013). Plant Soil 2013, 378, 1-33. [CrossRef]

129. Owen, D.; Williams, A.P.; Griffith, G.; Withers, P.J.A. Use of commercial bio-inoculants to increase agricultural production through improved phosphrous acquisition. Appl. Soil Ecol. 2015, 86, 41-54. [CrossRef]

130. Khan, M.S.; Zaidi, A.; Wani, P.A.; Oves, M. Role of plant growth promoting rhizobacteria in the remediation of metal contaminated soils. Environ. Chem. Lett. 2008, 7, 1-19. [CrossRef]

131. Oleńska, E.; Małek, W.; Wójcik, M.; Swiecicka, I.; Thijs, S.; Vangronsveld, J. Beneficial features of plant growth-promoting rhizobacteria for improving plant growth and health in challenging conditions: A methodical review. Sci. Total Environ. 2020, 743, 140682. [CrossRef] [PubMed]

132. Ma, Y.; Prasad, M.; Rajkumar, M.; Freitas, H. Plant growth promoting rhizobacteria and endophytes accelerate phytoremediation of metalliferous soils. Biotechnol. Adv. 2011, 29, 248-258. [CrossRef] [PubMed]

133. Arslan, M.; Afzal, M.; Amin, I.; Iqbal, S.; Khan, Q.M. Nutrients Can Enhance the Abundance and Expression of Alkane Hydroxylase CYP153 Gene in the Rhizosphere of Ryegrass Planted in Hydrocarbon-Polluted Soil. PLoS ONE 2014, 9, e111208. [CrossRef]

134. Balseiro-Romero, M.; Gkorezis, P.; Kidd, P.; Van Hamme, J.; Weyens, N.; Monterroso, C.; Vangronsveld, J. Use of plant growth promoting bacterial strains to improve Cytisus striatus and Lupinus luteus development for potential application in phytoremediation. Sci. Total Environ. 2017, 581-582, 676-688. [CrossRef]

135. Pizarro-Tobias, P.; Niqui, J.L.; Roca, A.; Solano, J.; Fernández, M.; Bastida, F.; García, C.; Ramos, J.L. Field trial on removal of petroleum-hydrocarbon pollutants using a microbial consortium for bioremediation and rhizoremediation. Environ. Microbiol. Rep. 2014, 7, 85-94. [CrossRef] 
136. Hou, J.; Liu, W.; Wang, B.; Wang, Q.; Luo, Y.; Franks, A. PGPR enhanced phytoremediation of petroleum contaminated soil and rhizosphere microbial community response. Chemosphere 2015, 138, 592-598. [CrossRef] [PubMed]

137. Ptaszek, N.; Pacwa-Płociniczak, M.; Noszczyńska, M.; Płociniczak, T. Comparative Study on Multiway Enhanced Bio- and Phytoremediation of Aged Petroleum-Contaminated Soil. Agronomy 2020, 10, 19. [CrossRef]

138. Płociniczak, T.; Fic, E.; Pacwa-Płociniczak, M.; Pawlik, M.; Piotrowska-Seget, Z. Improvement of phytoremediation of an aged petroleum hydrocarbon-contaminated soil by Rhodococcus erythropolis CD 106 strain. Int. J. Phytoremediat. 2017, 19, 614-620. [CrossRef]

139. Whyte, L.G.; Schultz, A.; Beilen, J.B.; Luz, A.P.; Pellizari, V.; Labbã, D.; Greer, C.W.; Labbé, D. Prevalence of alkane monooxygenase genes in Arctic and Antarctic hydrocarbon-contaminated and pristine soils1. FEMS Microbiol. Ecol. 2002, 41, 141-150. [CrossRef]

140. Yakimov, M.; Timmis, K.N.; Golyshin, P. Obligate oil-degrading marine bacteria. Curr. Opin. Biotechnol. 2007, 18, 257-266. [CrossRef]

141. Afzal, M.; Yousaf, S.; Reichenauer, T.G.; Sessitsch, A. Ecology of Alkane-Degrading Bacteria and Their Interaction with the Plant. Mol. Microb. Ecol. Rhizosphere 2013, 2, 975-989. [CrossRef]

142. Johnsen, A.R.; Karlson, U. PAH Degradation Capacity of Soil Microbial Communities—Does It Depend on PAH Exposure? Microb. Ecol. 2005, 50, 488-495. [CrossRef]

143. Tremblay, J.; Yergeau, E.; Fortin, N.; Cobanli, S.; Elias, M.; King, T.L.; Lee, K.; Greer, C.W. Chemical dispersants enhance the activity of oil- and gas condensate-degrading marine bacteria. ISME J. 2017, 11, 2793-2808. [CrossRef] [PubMed]

144. Xu, X.; Liu, W.; Tian, S.; Wang, W.; Qi, Q.; Jiang, P.; Gao, X.; Li, F.; Li, H.; Yu, H. Petroleum Hydrocarbon-Degrading Bacteria for the Remediation of Oil Pollution Under Aerobic Conditions: A Perspective Analysis. Front. Microbiol. 2018, 9, 2885. [CrossRef]

145. Varjani, S.J. Microbial degradation of petroleum hydrocarbons. Bioresour. Technol. 2017, 223, 277-286. [CrossRef] [PubMed]

146. Wang, X.-B.; Chi, C.-Q.; Nie, Y.; Tang, Y.-Q.; Tan, Y.; Wu, G.; Wu, X.-L. Degradation of petroleum hydrocarbons (C6-C40) and crude oil by a novel Dietzia strain. Bioresour. Technol. 2011, 102, 7755-7761. [CrossRef]

147. Sarkar, P.; Roy, A.; Pal, S.; Mohapatra, B.; Kazy, S.K.; Maiti, M.K.; Sar, P. Enrichment and characterization of hydrocarbondegrading bacteria from petroleum refinery waste as potent bioaugmentation agent for in situ bioremediation. Bioresour. Technol. 2017, 242, 15-27. [CrossRef]

148. Rojo, F. Degradation of alkanes by bacteria. Environ. Microbiol. 2009, 11, 2477-2490. [CrossRef]

149. Post-Beittenmiller, D. Biochemistry and molecular biology of wax production in plants. Annu. Rev. Plant Biol. 1996, 47, 405-430. [CrossRef]

150. Schirmer, A.; Rude, M.A.; Li, X.; Popova, E.; del Cardayre, S.B. Microbial Biosynthesis of Alkanes. Science 2010, $329,559-562$. [CrossRef]

151. Ji, Y.; Mao, G.; Wang, Y.; Bartlam, M. Structural insights into diversity and n-alkane biodegradation mechanisms of alkane hydroxylases. Front. Microbiol. 2013, 4, 58. [CrossRef]

152. Nie, Y.; Chi, C.-Q.; Fang, H.; Liang, J.-L.; Lu, S.-L.; Lai, G.-L.; Tang, Y.-Q.; Wu, X.-L. Diverse alkane hydroxylase genes in microorganisms and environments. Sci. Rep. 2014, 4, 4968. [CrossRef] [PubMed]

153. Van Beilen, J.B.; Funhoff, E.G. Alkane hydroxylases involved in microbial alkane degradation. Appl. Microbiol. Biotechnol. 2007, 74, 13-21. [CrossRef] [PubMed]

154. Wang, W.; Shao, Z. Enzymes and genes involved in aerobic alkane degradation. Front. Microbiol. 2013, 4, 116. [CrossRef] [PubMed]

155. Bihari, Z.; Szvetnik, A.; Szabó, Z.; Blastyák, A.; Zombori, Z.; Balázs, M.; Kiss, I. Functional analysis of long-chain n-alkane degradation by Dietzia spp. FEMS Microbiol. Lett. 2011, 316, 100-107. [CrossRef]

156. Piccolo, L.L.; DE Pasquale, C.; Fodale, R.; Puglia, A.M.; Quatrini, P. Involvement of an Alkane Hydroxylase System of Gordonia sp. Strain SoCg in Degradation of Solid n -Alkanes. Appl. Environ. Microbiol. 2011, 77, 1204-1213. [CrossRef]

157. van Beilen, J.B.; Funhoff, E.G.; van Loon, A.; Just, A.; Kaysser, L.; Bouza, M.; Holtackers, R.; Röthlisberger, M.; Li, Z.; Witholt, B. Cytochrome P450 Alkane Hydroxylases of the CYP153 Family Are Common in Alkane-Degrading Eubacteria Lacking Integral Membrane Alkane Hydroxylases. Appl. Environ. Microbiol. 2006, 72, 59-65. [CrossRef]

158. Nie, Y.; Liang, J.-L.; Fang, H.; Tang, Y.-Q.; Wu, X.-L. Characterization of a CYP153 alkane hydroxylase gene in a Gram-positive Dietzia sp. DQ12-45-1b and its "team role" with alkW1 in alkane degradation. Appl. Microbiol. Biotechnol. 2013, 98, 163-173. [CrossRef]

159. Whyte, L.G.; Smits, T.H.M.; Labbé, D.; Witholt, B.; Greer, C.W.; van Beilen, J.B. Gene Cloning and Characterization of Multiple Alkane Hydroxylase Systems in Rhodococcus Strains Q15 and NRRL B-16531. Appl. Environ. Microbiol. 2002, 68, 5933-5942. [CrossRef]

160. Wang, L.; Wang, W.; Lai, Q.; Shao, Z. Gene diversity of CYP153A and AlkB alkane hydroxylases in oil-degrading bacteria isolated from the Atlantic Ocean. Environ. Microbiol. 2010, 12, 1230-1242. [CrossRef] [PubMed]

161. Long, H.; Wang, Y.; Chang, S.; Liu, G.; Chen, T.; Huo, G.; Zhang, W.; Wu, X.; Tai, X.; Sun, L.; et al. Diversity of crude oil-degrading bacteria and alkane hydroxylase (alkB) genes from the Qinghai-Tibet Plateau. Environ. Monit. Assess. 2017, 189, 116. [CrossRef]

162. Varjani, S.J.; Gnansounou, E.; Pandey, A. Comprehensive review on toxicity of persistent organic pollutants from petroleum refinery waste and their degradation by microorganisms. Chemosphere 2017, 188, 280-291. [CrossRef]

163. Perez-Pantoja, D.; Gonza'lez, B.; Pieper, D.H. Aerobic Degradation of Aromatic Hydrocarbons. In Handbook of Hydrocarbon and Lipid Microbiology; Timmis, K.N., Ed.; Springer: Berlin/Heidelberg, Germany, 2010; pp. 800-837. 
164. Kotoky, R.; Rajkumari, J.; Pandey, P. The rhizosphere microbiome: Significance in rhizoremediation of polyaromatic hydrocarbon contaminated soil. J. Environ. Manag. 2018, 217, 858-870. [CrossRef]

165. Cerniglia, C.E. Biodegradation of polycyclic aromatic hydrocarbons. Biodegradation 1992, 3, 351-368. [CrossRef]

166. Peng, R.-H.; Xiong, A.-S.; Xue, Y.; Fu, X.-Y.; Gao, F.; Zhao, W.; Tian, Y.-S.; Yao, Q.-H. Microbial biodegradation of polyaromatic hydrocarbons. FEMS Microbiol. Rev. 2008, 32, 927-955. [CrossRef] [PubMed]

167. Mallick, S.; Chakraborty, J.; Dutta, T.K. Role of oxygenases in guiding diverse metabolic pathways in the bacterial degradation of low-molecular-weight polycyclic aromatic hydrocarbons: A review. Crit. Rev. Microbiol. 2010, 37, 64-90. [CrossRef] [PubMed]

168. Ghosal, D.; Ghosh, S.; Dutta, T.K.; Ahn, Y. Current State of Knowledge in Microbial Degradation of Polycyclic Aromatic Hydrocarbons (PAHs): A Review. Front. Microbiol. 2016, 7, 1369. [CrossRef]

169. Kweon, O.; Kim, S.-J.; Cerniglia, C.E. An Update on the Genomic View of Mycobacterial High-Molecular-Weight Polycyclic Aromatic Hydrocarbon Degradation. In Aerobic Utilization of Hydrocarbons, Oils and Lipids, Handbook of Hydrocarbon and Lipid Microbiology; Rojo, F., Ed.; Springer: Berlin/Heidelberg, Germany, 2018; pp. 1-16.

170. Wick, A.D.M.L.; De Munain, A.R.; Springael, D.; Harms, H. Responses of Mycobacterium sp. LB501T to the low bioavailability of solid anthracene. Appl. Microbiol. Biotechnol. 2002, 58, 378-385. [CrossRef]

171. Simon, M.J.; Osslund, T.D.; Saunders, R.; Ensley, B.D.; Suggs, S.; Harcourt, A.; Wen-Chen, S.; Cruder, D.L.; Gibson, D.T.; Zylstra, G.J. Sequences of genes encoding naphthalene dioxygenase in Pseudomonas putida strains G7 and NCIB 9816-4. Gene 1993, 127, 31-37. [CrossRef]

172. Laurie, A.D.; Lloyd-Jones, G. The phn Genes of Burkholderia sp. Strain RP007 Constitute a Divergent Gene Cluster for Polycyclic Aromatic Hydrocarbon Catabolism. J. Bacteriol. 1999, 181, 531-540. [CrossRef] [PubMed]

173. Khan, A.A.; Wang, R.-F.; Cao, W.-W.; Doerge, D.R.; Wennerstrom, D.; Cerniglia, C.E. Molecular Cloning, Nucleotide Sequence, and Expression of Genes Encoding a Polycyclic Aromatic Ring Dioxygenase from Mycobacterium sp. Strain PYR-1. Appl. Environ. Microbiol. 2001, 67, 3577-3585. [CrossRef] [PubMed]

174. Pagnout, C.; Frache, G.; Poupin, P.; Maunit, B.; Muller, J.-F.; Férard, J.-F. Isolation and characterization of a gene cluster involved in PAH degradation in Mycobacterium sp. strain SNP11: Expression in Mycobacterium smegmatis mc2155. Res. Microbiol. 2007, 158, 175-186. [CrossRef] [PubMed]

175. Kivisaar, M.; Kasak, L.; Nurk, A. Sequence of the plasmid-encoded catechol 1,2-dioxygenase-expressing gene, pheB, of phenoldegrading Pseudomonas sp. strain EST1001. Gene 1991, 98, 15-20. [CrossRef]

176. Hiraoka, S.; Yang, C.-C.; Iwasaki, W. Metagenomics and Bioinformatics in Microbial Ecology: Current Status and Beyond. Microbes Environ. 2016, 31, 204-212. [CrossRef] [PubMed]

177. Equiza, L.; St-Arnaud, M.; Eyergeau, E. Harnessing phytomicrobiome signaling for rhizosphere microbiome engineering. Front. Plant Sci. 2015, 6, 507. [CrossRef]

178. Tardif, S.; Yergeau, E.; Tremblay, J.; Legendre, P.; Whyte, L.G.; Greer, C.W. The Willow Microbiome Is Influenced by Soil Petroleum-Hydrocarbon Concentration with Plant Compartment-Specific Effects. Front. Microbiol. 2016, 7, 1363. [CrossRef] [PubMed]

179. Mitter, E.K.; De Freitas, J.R.; Germida, J.J. Bacterial Root Microbiome of Plants Growing in Oil Sands Reclamation Covers. Front. Microbiol. 2017, 8, 849. [CrossRef]

180. Ofek-Lalzar, M.; Sela, N.; Goldman-Voronov, M.; Green, S.; Hadar, Y.; Minz, D. Niche and host-associated functional signatures of the root surface microbiome. Nat. Commun. 2014, 5, 4950. [CrossRef] [PubMed]

181. Bell, T.H.; Joly, S.; Pitre, F.E.; Yergeau, E. Increasing phytoremediation efficiency and reliability using novel omics approaches. Trends Biotechnol. 2014, 32, 271-280. [CrossRef]

182. Pagé, A.P.; Yergeau, E.; Greer, C.W. Salix purpurea Stimulates the Expression of Specific Bacterial Xenobiotic Degradation Genes in a Soil Contaminated with Hydrocarbons. PLoS ONE 2015, 10, e0132062. [CrossRef]

183. Zhao, Q.; Hu, H.; Wang, W.; Peng, H.; Zhang, X. Genome Sequence of Sphingobium yanoikuyae B1, a Polycyclic Aromatic Hydrocarbon-Degrading Strain. Genome Announc. 2015, 3, e01522-14. [CrossRef]

184. Imperato, V.; Portillo-Estrada, M.; McAmmond, B.; Douwen, Y.; Van Hamme, J.D.; Gawronski, S.W.; Vangronsveld, J.; Thijs, S. Genomic Diversity of Two Hydrocarbon-Degrading and Plant Growth-Promoting Pseudomonas Species Isolated from the Oil Field of Bóbrka (Poland). Genes 2019, 10, 443. [CrossRef]

185. Neifar, M.; Chouchane, H.; Najjari, A.; El Hidri, D.; Mahjoubi, M.; Ghedira, K.; Naili, F.; Soufi, L.; Raddadi, N.; Sghaier, H.; et al. Genome analysis provides insights into crude oil degradation and biosurfactant production by extremely halotolerant Halomonas desertis G11 isolated from Chott El-Djerid salt-lake in Tunisian desert. Genomics 2018, 111, 1802-1814. [CrossRef]

186. He, C.; Li, Y.; Huang, C.; Chen, F.; Ma, Y. Genome Sequence and Metabolic Analysis of a Fluoranthene-Degrading Strain Pseudomonas aeruginosa DN1. Front. Microbiol. 2018, 9, 2595. [CrossRef] [PubMed]

187. Mahjoubi, M.; Aliyu, H.; Cappello, S.; Naifer, M.; Souissi, Y.; Cowan, D.; Cherif, A. The genome of Alcaligenes aquatilis strain BU33N: Insights into hydrocarbon degradation capacity. PLoS ONE 2019, 14, e0221574. [CrossRef]

188. Silva, N.M.; De Oliveira, A.M.S.A.; Pegorin, S.; Giusti, C.E.; Ferrari, V.; Barbosa, D.; Martins, L.F.; Morais, C.; Setubal, J.C.; Vasconcellos, S.P.; et al. Characterization of novel hydrocarbon-degrading Gordonia paraffinivorans and Gordonia sihwensis strains isolated from composting. PLoS ONE 2019, 14, e0215396. [CrossRef] 
189. Rajkumari, J.; Singha, L.P.; Pandey, P. Draft Genome Sequence of Klebsiella pneumoniae AWD5. Genome Announc. 2017, 5, e01531-16. [CrossRef]

190. Stevens, V.; Thijs, S.; McAmmond, B.; Langill, T.; Van Hamme, J.; Weyens, N.; Vangronsveld, J. Draft Genome Sequence of Bacillus licheniformis VSD4, a Diesel Fuel-Degrading and Plant Growth-Promoting Phyllospheric Bacterium. Genome Announc. 2017, 5, e00027-17. [CrossRef]

191. Filonov, A.; Delegan, Y.; Puntus, I.; Valentovich, L.; Akhremchuk, A.; Evdokimova, O.; Funtikova, T.; Zakharova, M.; Akhmetov, L.; Vetrova, A.; et al. Complete Genome Sequence of Pseudomonas putida BS3701, a Promising Polycyclic Aromatic HydrocarbonDegrading Strain for Bioremediation Technologies. Microbiol. Resour. Announc. 2020, 9, e00892-20. [CrossRef] 